\title{
Genetic, histochemical and biochemical studies on goat TSE cases from Cyprus
}

\author{
Susanne Niedermeyer ${ }^{1}$, Martin Eiden ${ }^{1}$, Pavlos Toumazos², Penelope Papasavva-Stylianou ${ }^{2}$, Ioannis loannou ${ }^{2}$, \\ Theodoros Sklaviadis ${ }^{3}$, Cynthia Panagiotidis ${ }^{3}$, Jan Langeveld ${ }^{4}$, Alex Bossers ${ }^{4}$, Thorsten Kuczius ${ }^{5}$, Martin Kaatz ${ }^{1}$, \\ Martin H. Groschup ${ }^{1}$ and Christine Fast ${ }^{1^{*}(\text { i) }}$
}

\begin{abstract}
Scrapie and bovine spongiform encephalopathy (BSE) are transmissible spongiform encephalopathies (TSE's) affecting sheep and goats. Susceptibility of goats to scrapie is influenced by polymorphisms of the prion protein gene (PRNP) of the host. Five polymorphisms are associated with reduced susceptibility to TSE's. In the study presented here caprine samples from a scrapie eradication program on Cyprus were genotyped and further characterized using BioRad TeSeE rapid test, histological, immunohistochemical and biochemical methods. In total 42 goats from 20 flocks were necropsied from which 25 goats showed a positive result in the rapid test, a spongiform encephalopathy and an accumulation of pathological prion protein $\left(\mathrm{Pr}^{\mathrm{SC}}\right)$ in the obex. $\mathrm{Pr} \mathrm{P}^{\mathrm{Sc}}$ deposits were demonstrated in the placenta, peripheral nervous and lymphoreticular system. Two animals showed PrPSc-accumulations in peripheral tissues only. By discriminatory immunoblots a scrapie infection could be confirmed for all cases. Nevertheless, slight deviations in the glycosylation pattern might indicate the presence of different scrapie strains. Furthermore scrapie samples from goats in the current study demonstrated less long term resistance to proteinase K than ovine or caprine BSE control samples. Reduced scrapie susceptibility according to the PRNP genotype was demonstrated (Fishers Exact test, $p<0.05)$ for the goats with at least one polymorphism $(p=0.023)$ at the six codons examined and in particular for those with polymorphisms at codon $146(p=0.016)$. This work characterizes scrapie in goats having implications for breeding and surveillance strategies.
\end{abstract}

\section{Introduction}

Transmissible spongiform encephalopathies (TSE's) are progressive, fatal neurodegenerative diseases in humans and mammals. Causative is the conversion of the cellular membrane bound prion protein $\left(\mathrm{PrP}^{\mathrm{c}}\right)$ into a partially protease-resistant pathologic form $\left(\mathrm{PrP}^{\mathrm{Sc}}\right)$ [1]. TSE's are characterized by long incubation periods of several months or even years. Among others, there is scrapie in sheep, goats and mufflons [2-4] and also bovine spongiform encephalopathy which was first described in cattle in 1986 [5] being the only animal prion disease confirmed to affect human beings (Creutzfeldt-Jakob disease) and mammals [6].

\footnotetext{
*Correspondence: Christine.Fast@fli.bund.de

${ }^{1}$ Institute of Novel and Emerging Infectious Diseases, Friedrich-LoefflerInstitute, Südufer 10, 17493 Greifswald-Isle of Riems, Germany Full list of author information is available at the end of the article
}

The first natural caprine scrapie case was not reported before 1942 [2], and, apart from diverse outbreaks in cattle, natural BSE infection was only diagnosed in one single British goat in 2005 [7]. Later on, a Scottish goat with BSE disease from 1990 was revealed in retrospective studies in the United Kingdom [8]. To date, natural BSE was never detected in sheep though the disease was successfully transmitted to sheep and goats under experimental conditions [9]. As already described for sheep, the susceptibility of goats for scrapie is highly influenced by polymorphisms of the prion protein gene (PRNP). To date, more than 40 polymorphisms of the caprine PRNP have been described in different countries and breeds [10-14]. Among these, only five polymorphisms were found which seem to correlate with TSE susceptibility. The polymorphisms I142M and R154H extend incubation period and for the latter partially protective effects had been described $[12,13,15,16]$. Effects on resistance 
against TSE were associated with the polymorphisms N146S/D, R211Q and Q222K polymorphisms [12, 13, 17, 18].

As described for sheep, goats are typically diagnosed with scrapie at the age of 3 to 4 years [19], and clinical signs last from 2 weeks to 6 months [19-21]. Apathy, ataxia, severe pruritus, difficulties in milking and loss of weight are clinical signs seen in affected goats [20]. For sheep it is known that scrapie is transmitted horizontally under natural conditions via direct contact or from contaminated environment $[22,23]$. The oral route is the most efficient entrance for the TSE material and the placenta after birth is the main source of infection [24-26]. However, $\mathrm{PrP}^{\mathrm{Sc}}$ and/or infectivity have also been found in amniotic fluid [26], faeces [27], milk [28, 29] and even in the oral cavity of scrapie infected sheep [30]. Scrapie in goats is often found in mixed herds together with sheep $[2,31]$, but it has also been observed to spread from goat to goat [19].

Pathogenesis of scrapie has been widely described in sheep and to a lesser extent in goats. In sheep, first accumulations of $\operatorname{PrP}^{\mathrm{Sc}}$ can be immunohistochemically detected in the tonsils and the gut associated lymphatic tissue such as the Peyers' patches of the ileum and jejunum after oral ingestion [32-34].

Later on, $\operatorname{PrP}^{\mathrm{Sc}}$ spreads and accumulates in the corresponding mesenteric lymph nodes $[33,35,36]$ as well as in peripheral lymph nodes and the spleen $[35,37] . \mathrm{PrP}^{\mathrm{Sc}}$ deposits were also detected in the enteric nervous system with duodenum and ileum as first positive sites and with the tendency to spread extensively in the cranial and caudal parts of the ENS $[32,33]$. It is widely accepted that $\mathrm{PrP}^{\mathrm{Sc}}$ ascends along the parasympathetic and/or sympathetic nerve fibres with finally reaching the brain and the spinal cord, respectively [32]. As an additional pathway the hematogenous distribution of $\mathrm{PrP}^{\mathrm{Sc}}$ is discussed considering $\mathrm{PrP}^{\mathrm{Sc}}$ infectivity which was found in ovine blood [38] as well as the infection of the brain via circumventricular organs [39]. Studies describing natural scrapie in goats are rare but the data known so far indicate that the spread of $\operatorname{PrP}^{\mathrm{Sc}}$ is comparable to classical scrapie in sheep [40-43]. However there can be a distinct variability among individual animals, which, among other things, might be due to a high variability of classical scrapie strains and their interactions with the particular genotype of the host [41].

Scrapie is spread nearly worldwide in sheep and goats $[10,31,44,45]$. In Cyprus, scrapie has been a major problem for animal husbandry since the first detection in 1985 [31]. Thus within the European Union between 2007 and 2009 , about $90 \%$ of the positive goat scrapie cases were found in Cyprus [41]. The applied extensive eradication programs were a unique possibility to collect samples from goats which were naturally infected with scrapie.

The study presented here describes a biochemical and immunohistochemical characterization of natural goat scrapie cases including PRNP genetics. It is aimed to shed more light on the pathogenesis of this disease in goats and also to characterize the diversity of natural scrapie strains on Cyprus more precisely excluding possible BSE cases at the same time.

\section{Materials and methods}

\section{Animals}

The goats were chosen within the framework of a scrapie eradication program that has been implemented in Cyprus. All animals were killed in accordance to the European animal welfare regulations. In total 42 Cypriot female goats of a local Damascus breed that were showing scrapie like clinical signs (alopecia, cachexia and/or ataxia) were sourced out from twenty flocks of the Nicosia district. Afterwards these goats of different ages were dissected in the facilities of the Veterinary Services (VS), Ministry of Agriculture, Rural Development and Environment, 1417 Nicosia, Cyprus. Beside blood samples a wide range of frozen and formalin fixed tissue samples were taken under TSE sterile conditions. All the 42 goats were kept together with sheep or were kept on pastures which formerly used sheep for grazing. Data of all goats are given in Tables 1 and 2.

\section{Genotyping}

The genotyping of the codons 142, 146, 151, 154, 211 and 222 of the prion protein gene (PRNP) was done by C. H. Panagiotidis at the Aristotle University in Thessaloniki Greece using the cycle-sequencing method formerly described [46].

\section{Tissue samples}

Selected tissue samples were examined following different analysis procedures (Figure 1). Brain stem material (obex region) of all 42 goats was examined histologically, immunohistochemically and biochemically. Further samples were examined immunohistochemically only. In this case, to limit the samples sizes which had to be examined, the most likely sites of $\mathrm{PrP}^{\mathrm{Sc}}$ accumulations such as the retropharyngeal lymph node, tonsils, third eye lid, spleen, celiac and mesenteric ganglion complex (CMGC) and rectum of all goats were examined in a first step. In a second step, samples of the kidney, mammary gland, uterus and, if available, placentomal tissue of the placenta were examined with only taking the goats into account which revealed $\mathrm{PrP}^{\mathrm{Sc}}$ positive results in the tissue samples analysed previously. 
Table 1 Data and results of scrapie positive Damascus goats from Cyprus

\begin{tabular}{|c|c|c|c|c|c|c|c|c|c|c|}
\hline \multirow{2}{*}{$\begin{array}{l}\text { Goat } \\
\text { ZYP }\end{array}$} & \multirow{2}{*}{$\begin{array}{l}\text { Flock } \\
\text { (age) }\end{array}$} & \multirow{2}{*}{$\begin{array}{l}\text { Brain stem } \\
\text { IHC (rapid } \\
\text { test) }\end{array}$} & \multirow[t]{2}{*}{ CM GC } & \multirow[t]{2}{*}{ Ln. retroph. } & \multirow[t]{2}{*}{ Tonsil } & \multirow[t]{2}{*}{$3^{\text {rd }}$ eye lid } & \multirow[t]{2}{*}{ Spleen } & \multicolumn{2}{|l|}{ Rectum } & \multirow[t]{2}{*}{ Placenta } \\
\hline & & & & & & & & Follicles & ENS & \\
\hline \multicolumn{11}{|c|}{$\mathrm{I}_{142} \mathrm{~N}_{146} \mathrm{R}_{151} \mathrm{R}_{154} \mathrm{R}_{211} \mathrm{Q}_{222}$} \\
\hline 3 & $B(4)$ & $\begin{array}{l}+++ \\
(1.892)\end{array}$ & + & NA & $\begin{array}{l}+++ \\
9 / 9\end{array}$ & $\begin{array}{l}+++ \\
13 / 19\end{array}$ & $\begin{array}{l}++ \\
83 / 202\end{array}$ & $\begin{array}{c}+++ \\
1 / 1\end{array}$ & neg. & neg. \\
\hline 8 & $C(4)$ & $\begin{array}{l}+++ \\
(1.675)\end{array}$ & NA & $\begin{array}{l}+++ \\
4 / 4\end{array}$ & $\begin{array}{l}\text { neg. } \\
0 / 5\end{array}$ & $\begin{array}{l}+++ \\
7 / 12\end{array}$ & $+\underset{6 / 140}{+}$ & $\begin{array}{l}\text { neg. } \\
0 / 3\end{array}$ & $\stackrel{+}{\text { Pl.my. }}$ & NA \\
\hline 9 & $D(4)$ & $\begin{array}{l}++ \\
(1.579)\end{array}$ & ++ & $\begin{array}{l}+++ \\
625 / 830\end{array}$ & $\begin{array}{l}+++ \\
96 / 120\end{array}$ & $\begin{array}{l}+++ \\
35 / 64\end{array}$ & $\begin{array}{l}+++ \\
110 / 162\end{array}$ & $\begin{array}{l}+++ \\
19 / 24\end{array}$ & neg. & neg. \\
\hline 10 & $E(3)$ & $\begin{array}{l}+++ \\
(1.985)\end{array}$ & NA & $\begin{array}{l}+++ \\
232 / 646\end{array}$ & $\begin{array}{l}++ \\
124 / 213\end{array}$ & $\begin{array}{c}+++ \\
5 / 18\end{array}$ & $\begin{array}{l}+ \\
93 / 428\end{array}$ & $\begin{array}{l}+++ \\
37 / 48\end{array}$ & $\begin{array}{l}+ \\
\text { Pl.my. }\end{array}$ & neg. \\
\hline 11 & $F(4)$ & $\begin{array}{l}+++ \\
(1.856)\end{array}$ & + & $\begin{array}{l}+ \\
93 / 284\end{array}$ & $\begin{array}{l}+++ \\
124 / 255\end{array}$ & $\begin{array}{l}\text { neg. } \\
0 / 18\end{array}$ & $+\underset{10 / 374}{+}$ & $\begin{array}{l}\text { neg. } \\
\text { 0/19 }\end{array}$ & $\stackrel{+}{\text { Pl.my. }}$ & neg. \\
\hline 12 & G (3) & $\begin{array}{l}+++ \\
(2.193)\end{array}$ & ++ & $\begin{array}{l}++ \\
190 / 502\end{array}$ & 0 & $\stackrel{+}{9 / 46}$ & $\stackrel{+}{126 / 396}$ & $\begin{array}{l}++ \\
71 / 152\end{array}$ & neg. & neg. \\
\hline 13 & G (4) & $\begin{array}{l}+++ \\
(1.992)\end{array}$ & +++ & $\begin{array}{l}+ \\
87 / 365\end{array}$ & $\begin{array}{l}+++ \\
111 / 145\end{array}$ & $\begin{array}{l}+++ \\
4 / 4\end{array}$ & $\begin{array}{l}+++ \\
56 / 99\end{array}$ & $\begin{array}{l}+++ \\
131 / 174\end{array}$ & $\begin{array}{l}++ \\
\text { Pl.my/+sub. }\end{array}$ & NA \\
\hline 14 & $F(4)$ & $\begin{array}{l}+++ \\
(1.871)\end{array}$ & +++ & $\begin{array}{l}+++ \\
77 / 139\end{array}$ & $\begin{array}{l}++ \\
174 / 307\end{array}$ & $\begin{array}{l}+++ \\
5 / 5\end{array}$ & $\begin{array}{l}+++ \\
167 / 246\end{array}$ & $\begin{array}{l}+++ \\
28 / 46\end{array}$ & $\begin{array}{l}++ \\
\text { Pl.my/+sub. }\end{array}$ & neg. \\
\hline 16 & $H(4)$ & $\begin{array}{l}+++ \\
(2.204)\end{array}$ & +++ & $\begin{array}{l}+ \\
147 / 363\end{array}$ & $\begin{array}{l}+ \\
20 / 78\end{array}$ & + & $\begin{array}{l}+ \\
64 / 270\end{array}$ & $\begin{array}{l}++ \\
19 / 47\end{array}$ & $\stackrel{+}{\text { Pl.my/+sub. }}$ & NA \\
\hline 17 & $H(4)$ & $\begin{array}{l}+++ \\
(2.107)\end{array}$ & ++ & $\begin{array}{l}++ \\
119 / 300\end{array}$ & $\begin{array}{l}+++ \\
72 / 132\end{array}$ & $\begin{array}{c}+++ \\
15 / 17\end{array}$ & ${ }_{65 / 160}^{+}$ & $\begin{array}{l}+++ \\
29 / 43\end{array}$ & $\begin{array}{l}+ \\
\text { Pl.my. }\end{array}$ & NA \\
\hline 19 & $\mathrm{H}(4)$ & $\begin{array}{l}++ \\
(1.831)\end{array}$ & + & $\begin{array}{l}++ \\
50 / 131\end{array}$ & $\begin{array}{l}+ \\
15 / 82\end{array}$ & $\begin{array}{l}+ \\
1 / 9\end{array}$ & $\begin{array}{l}+++ \\
148 / 234\end{array}$ & $\begin{array}{l}+++ \\
2 / 2\end{array}$ & $\begin{array}{l}++ \\
\text { Pl.my. }\end{array}$ & NA \\
\hline 20 & I (3) & $\begin{array}{l}+++ \\
(1.961)\end{array}$ & + & $\begin{array}{l}++ \\
18 / 57\end{array}$ & $\begin{array}{l}+++ \\
268 / 335\end{array}$ & $\begin{array}{l}+ \\
2 / 7\end{array}$ & $\begin{array}{l}++ \\
123 / 373\end{array}$ & $\begin{array}{l}+++ \\
26 / 43\end{array}$ & $\begin{array}{l}++ \\
\text { Pl.my/+sub. }\end{array}$ & neg. \\
\hline 21 & $J(5)$ & $\begin{array}{l}++ \\
(1.511)\end{array}$ & +++ & $\begin{array}{l}+ \\
190 / 615\end{array}$ & NA & + & $\begin{array}{l}++ \\
175 / 314\end{array}$ & $\begin{array}{l}+ \\
20 / 37\end{array}$ & $\begin{array}{l}+++ \\
\text { Pl.my/+sub. }\end{array}$ & + \\
\hline 22 & $J(5)$ & $\begin{array}{l}++ \\
(1.151)\end{array}$ & NA & NA & $\begin{array}{l}+++ \\
65 / 96\end{array}$ & $\begin{array}{l}\text { neg. } \\
0 / 2\end{array}$ & $\begin{array}{l}+ \\
42 / 269\end{array}$ & $\begin{array}{l}+ \\
1 / 41\end{array}$ & $\begin{array}{l}+ \\
\text { Pl.my. }\end{array}$ & NA \\
\hline 25 & K (3) & $\begin{array}{l}++ \\
(1.227)\end{array}$ & ++ & ${ }_{278 / 654}^{+}$ & $\begin{array}{l}+++ \\
376 / 585\end{array}$ & $\begin{array}{l}+++ \\
3 / 4\end{array}$ & $\begin{array}{l}++ \\
173 / 339\end{array}$ & $\begin{array}{l}++ \\
4 / 14\end{array}$ & $\begin{array}{l}++ \\
\text { Pl.my/+sub. }\end{array}$ & NA \\
\hline 26 & $L(4)$ & $\begin{array}{l}++ \\
(1.731)\end{array}$ & + & $\begin{array}{l}+++ \\
196 / 302\end{array}$ & 0 & $\begin{array}{l}\text { neg. } \\
0 / 26\end{array}$ & $\begin{array}{l}+ \\
133 / 571\end{array}$ & $\begin{array}{l}+ \\
55 / 146\end{array}$ & $\begin{array}{l}+++ \\
\text { Pl.sub. }\end{array}$ & + \\
\hline 27 & M (3) & $\begin{array}{l}++ \\
(1.141)\end{array}$ & + & $\begin{array}{l}+++ \\
229 / 344\end{array}$ & $\begin{array}{c}+++ \\
41 / 65\end{array}$ & $\begin{array}{l}+++ \\
17 / 23\end{array}$ & $\begin{array}{l}+++ \\
82 / 152\end{array}$ & $\begin{array}{l}++ \\
10 / 28\end{array}$ & $\begin{array}{l}+++ \\
\text { Pl.my/+sub. }\end{array}$ & + \\
\hline 29 & M (4) & $\begin{array}{l}++ \\
(1.921)\end{array}$ & ++ & $\begin{array}{l}+++ \\
180 / 313\end{array}$ & ${ }_{290 / 459}^{+}$ & $\begin{array}{l}+++ \\
67 / 85\end{array}$ & $\begin{array}{l}+++ \\
125 / 128\end{array}$ & $\begin{array}{l}+++ \\
21 / 37\end{array}$ & $\begin{array}{l}++ \\
\text { Pl.my/+sub. }\end{array}$ & neg. \\
\hline 30 & M (6) & $\begin{array}{l}+++ \\
(1.246)\end{array}$ & ++ & $\begin{array}{l}++ \\
90 / 286\end{array}$ & $\begin{array}{l}+++ \\
72 / 139\end{array}$ & $\begin{array}{l}\text { neg. } \\
0 / 2\end{array}$ & $\begin{array}{l}+ \\
81 / 224\end{array}$ & $\begin{array}{l}+++ \\
17 / 22\end{array}$ & $\stackrel{+}{\text { Pl.my/+sub. }}$ & neg. \\
\hline 31 & $N(4)$ & $\begin{array}{l}++ \\
(1.255)\end{array}$ & ++ & $\begin{array}{l}+++ \\
264 / 398\end{array}$ & $\begin{array}{l}+++ \\
131 / 144\end{array}$ & $\begin{array}{l}+++ \\
26 / 55\end{array}$ & $\begin{array}{l}++ \\
169 / 366\end{array}$ & $\begin{array}{l}+++ \\
66 / 92\end{array}$ & $\begin{array}{l}+++ \\
\text { Pl.my/+sub. }\end{array}$ & neg. \\
\hline 33 & $O(2)$ & $\begin{array}{l}++ \\
(1.784)\end{array}$ & ++ & $\begin{array}{l}+++ \\
136 / 262\end{array}$ & $\begin{array}{l}+++ \\
141 / 164\end{array}$ & $\begin{array}{l}++ \\
3 / 10\end{array}$ & $\begin{array}{l}++ \\
257 / 503\end{array}$ & $\begin{array}{l}+++ \\
30 / 39\end{array}$ & $\begin{array}{l}++ \\
\text { Pl.my/+sub. }\end{array}$ & NA \\
\hline 34 & $P(2)$ & $\begin{array}{l}++ \\
(1.376)\end{array}$ & +++ & $\begin{array}{l}+++ \\
626 / 878\end{array}$ & $\begin{array}{l}+++ \\
191 / 256\end{array}$ & $\begin{array}{l}+++ \\
8 / 9\end{array}$ & $\begin{array}{l}+++ \\
228 / 292\end{array}$ & $\begin{array}{l}+++ \\
6 / 7\end{array}$ & $\begin{array}{l}+ \\
\text { Pl.my. }\end{array}$ & NA \\
\hline 35 & $P(4)$ & $\begin{array}{l}+++ \\
(1.452)\end{array}$ & NA & $\begin{array}{l}+++ \\
319 / 625\end{array}$ & $\begin{array}{l}+++ \\
73 / 147\end{array}$ & 0 & $\begin{array}{l}+ \\
4 / 208\end{array}$ & $\begin{array}{l}+ \\
9 / 101\end{array}$ & $\begin{array}{l}+ \\
\text { Pl.my. }\end{array}$ & neg. \\
\hline 41 & O (4) & $\begin{array}{l}++ \\
(1.674)\end{array}$ & NA & $\begin{array}{l}++ \\
97 / 268\end{array}$ & $\begin{array}{l}+++ \\
72 / 102\end{array}$ & $\begin{array}{l}\text { neg. } \\
0 / 14\end{array}$ & $\begin{array}{l}+ \\
60 / 167\end{array}$ & 0 & $\begin{array}{l}+ \\
\text { Pl.my. }\end{array}$ & NA \\
\hline 24 & K (2) & $\begin{array}{l}\text { neg. } \\
(0.012)\end{array}$ & + & $\begin{array}{l}+ \\
391 / 1154\end{array}$ & NA & $\begin{array}{l}\text { neg. } \\
0 / 42\end{array}$ & $\begin{array}{l}+ \\
11 / 446\end{array}$ & $\begin{array}{l}+ \\
8 / 80\end{array}$ & neg. & NA \\
\hline 37 & Q (3) & $\begin{array}{l}\text { neg. } \\
(0.010)\end{array}$ & + & $\begin{array}{l}\text { neg. } \\
0 / 168\end{array}$ & $\begin{array}{l}\text { neg. } \\
0 / 73\end{array}$ & $\begin{array}{l}\text { neg. } \\
0 / 8\end{array}$ & $\begin{array}{l}\text { neg. } \\
0 / 149\end{array}$ & $\begin{array}{l}\text { neg } \\
0 / 14\end{array}$ & neg. & NA \\
\hline
\end{tabular}


Table 1 continued

\begin{tabular}{|c|c|c|c|c|c|c|c|c|c|c|}
\hline \multirow{2}{*}{$\begin{array}{l}\text { Goat } \\
\text { ZYP }\end{array}$} & \multirow{2}{*}{$\begin{array}{l}\text { Flock } \\
\text { (age) }\end{array}$} & \multirow{2}{*}{$\begin{array}{l}\text { Brain stem } \\
\text { IHC (rapid } \\
\text { test) }\end{array}$} & \multirow[t]{2}{*}{ CM GC } & \multirow[t]{2}{*}{ Ln. retroph. } & \multirow[t]{2}{*}{ Tonsil } & \multirow[t]{2}{*}{$3^{\text {rd }}$ eye lid } & \multirow[t]{2}{*}{ Spleen } & \multicolumn{2}{|l|}{ Rectum } & \multirow[t]{2}{*}{ Placenta } \\
\hline & & & & & & & & Follicles & ENS & \\
\hline \multicolumn{11}{|c|}{$\mathrm{R} / \mathrm{H} 154$} \\
\hline 40 & $\mathrm{R}(4)$ & $\begin{array}{l}++ \\
(1.069)\end{array}$ & + & $\begin{array}{l}+ \\
21 / 220\end{array}$ & $\begin{array}{c}\text { neg. } \\
0 / 6\end{array}$ & $\begin{array}{c}\text { neg. } \\
0 / 6\end{array}$ & $\begin{array}{l}\text { neg. } \\
\text { o/134 }\end{array}$ & $\begin{array}{l}\text { neg. } \\
0 / 35\end{array}$ & $\begin{array}{l}+++ \\
\text { Pl.my. }\end{array}$ & neg. \\
\hline
\end{tabular}

D: aspartic acid; I: isoleucine; H: histidine; M: methionine; N: asparagine; Q: glutamine; R: arginine; S: serine; A-T: goat herds; age: is given in years; Cut-off BioRad rapid test: 0.213 ; IHC: immunohistochemistry;,,++++++ : mild, moderate, severe PrPSC accumulation (the first number indicates the number of positive follicles, the second number the total number of follicles examined); CMGC: celiac and mesenteric ganglion complex; Ln. retroph.: retropharyngeal lymph node; 0 : no lymphatic follicles; ENS: enteric nervous system; PI. my.+sub.: myenteric/submucosal plexus; neg.: PrPSc negative; NA: tissue sample not available.

Table 2 Data and results of all scrapie negative Damascus goats from Cyprus

\begin{tabular}{|c|c|c|c|c|c|c|c|c|c|c|}
\hline \multirow[t]{2}{*}{ Goat ZYP } & \multirow[t]{2}{*}{ Flock (age) } & \multirow{2}{*}{$\begin{array}{l}\text { Brain stem } \\
\text { IHC (rapid test) }\end{array}$} & \multirow[t]{2}{*}{ CM GC } & \multirow[t]{2}{*}{ Ln. retroph. } & \multirow[t]{2}{*}{ Tonsil } & \multirow[t]{2}{*}{$3^{\text {rd }}$ eye lid } & \multirow[t]{2}{*}{ Spleen } & \multicolumn{2}{|l|}{ Rectum } & \multirow[t]{2}{*}{ Placenta } \\
\hline & & & & & & & & Follicles & ENS & \\
\hline \multicolumn{11}{|c|}{$\mathrm{I}_{142} \mathrm{~N}_{146} \mathrm{R}_{151} \mathrm{R}_{154} \mathrm{R}_{211} \mathrm{Q}_{222}$} \\
\hline 6 & $A(7)$ & neg. (0.014) & neg. & neg. 0/120 & neg. 0/45 & neg. 0/13 & neg. 0/231 & NA & NA & NA \\
\hline 18 & $H(4)$ & neg. (0.016) & neg. & neg. 0/97 & neg. 0/111 & neg. 0/21 & neg. 0/3741 & neg. 0/9 & neg. & NA \\
\hline 23 & $K(6)$ & neg. (0.011) & neg. & neg. 0/110 & neg. 0/64 & neg. $0 / 3$ & neg. 0/201 & neg. 0/116 & neg. & NA \\
\hline 32 & $\mathrm{O}(4)$ & neg. (0.018) & neg. & neg. 0/401 & 0 & neg. 0/9 & neg. 0/173 & neg. 0/47 & neg. & NA \\
\hline 38 & $\mathrm{Q}(3)$ & neg. (0.010) & neg. & neg. 0/217 & neg. 0/186 & 0 & neg. 0/276 & neg. 0/49 & neg. & NA \\
\hline 42 & $S(2)$ & neg. (0.007) & neg. & neg. 0/388 & neg. 0/149 & neg. 0/1 & neg. 0/345 & neg. $0 / 5$ & neg. & neg. \\
\hline 43 & $S(3)$ & neg. (0.008) & neg. & neg. 0/98 & neg. 0/2 & neg. 0/39 & neg. 0/313 & neg. 0/35 & neg. & neg. \\
\hline 44 & $S(4)$ & neg. (0.008) & neg. & neg. 0/329 & neg. 0/73 & neg. 0/26 & neg. 0/306 & neg. 0/46 & neg. & NA \\
\hline 45 & $\mathrm{~T}(5)$ & neg. (0.010) & neg. & neg. 0/359 & neg. 0/132 & neg. 0/4 & neg. 0/223 & neg. 0/16 & neg. & NA \\
\hline 46 & $\mathrm{~T}(4)$ & neg. (0.010) & neg. & neg. 0/548 & neg. 0/195 & neg. 0/51 & neg. 0/294 & neg. 0/14 & neg. & NA \\
\hline \multicolumn{11}{|l|}{ N/S146 } \\
\hline 2 & $A(7)$ & neg. (0.017) & neg. & neg. 0/219 & neg. 0/86 & neg. 0/1 & neg. 0/267 & neg. 0/1 & neg. & NA \\
\hline \multicolumn{11}{|l|}{$\mathrm{S} 146$} \\
\hline 4 & $A(7)$ & neg. (0.049) & neg. & neg. 0/230 & neg. 0/158 & 0 & neg. 0/106 & neg. $0 / 2$ & neg. & NA \\
\hline \multicolumn{11}{|l|}{ N/D146 } \\
\hline 28 & $M(2)$ & neg. (0.010) & neg. & neg. 0/223 & neg. 0/204 & neg. 0/18 & neg. 0/207 & neg. 0/31 & neg. & NA \\
\hline \multicolumn{11}{|l|}{ M142 } \\
\hline 36 & $\mathrm{Q}(3)$ & neg. (0.010) & neg. & neg. 0/131 & neg. 0/49 & neg. $0 / 3$ & neg. 0/270 & neg. $0 / 2$ & neg. & NA \\
\hline \multicolumn{11}{|c|}{ N/D146R/H151 } \\
\hline 39 & $\mathrm{Q}(4)$ & neg. (0.007) & neg. & neg. 0/899 & neg. $0 / 2$ & neg. 0/21 & neg. 0/168 & neg. $0 / 3$ & neg. & neg. \\
\hline
\end{tabular}

D: aspartic acid; I: isoleucine; $\mathrm{H}$ : histidine; M: methionine; $\mathrm{N}$ : asparagine; Q: glutamine; R: arginine; S: serine; A-T: goat herds; age is given in years; Cut-off BioRad rapid test: 0.213 ; IHC: immunohistochemistry;,,++++++ : mild, moderate, severe PrPS $\mathrm{Pcc}^{\mathrm{Sc}}$ amulation (the first number indicates the number of positive follicles, the second number the total number of follicles examined); CMGC: celiac and mesenteric ganglion complex; Ln. retroph.: retropharyngeal lymph node; 0: no lymphatic follicles; ENS: enteric nervous system; neg.: PrPS negative; NA tissue sample not available.

\section{Histology and immunohistochemistry}

The tissue samples as well as the resulting sections were treated as described before [47] with following modifications. Sections were cut in serials by producing sections of up to three areas per paraffin block. The three areas were chosen in a $25-30 \mu \mathrm{m}$ distance what guaranteed a totally different cell layer in each area examined. Sections of all samples were stained with haematoxylin and eosin. For the detection of caprine $\operatorname{PrP}^{\mathrm{Sc}}$, the three different PrP-specific monoclonal antibodies (mAb) 6C2 (Central
Veterinary Institute of Wageningen UR, Lelystad, Netherlands), F99 (VMRD, Pullman, USA) and L42 [48] which were raised to the epitope 114-120 of bovine PrP protein (6C2) and to epitop 220-225 (F99) and epitop 145-163 (L42) of ovine PrP protein, respectively, were chosen. Before applying the antibodies, the sections had been pre-treated by incubation for $30 \mathrm{~min}$ (6C2, F99) or $15 \mathrm{~min}$ (L42) in 98\% formic acid and rinsed in tap water for $5 \mathrm{~min}$. After inhibiting the endogenous Peroxidase the sections had been autoclaved in citrate buffer for $20 \mathrm{~min}$ 


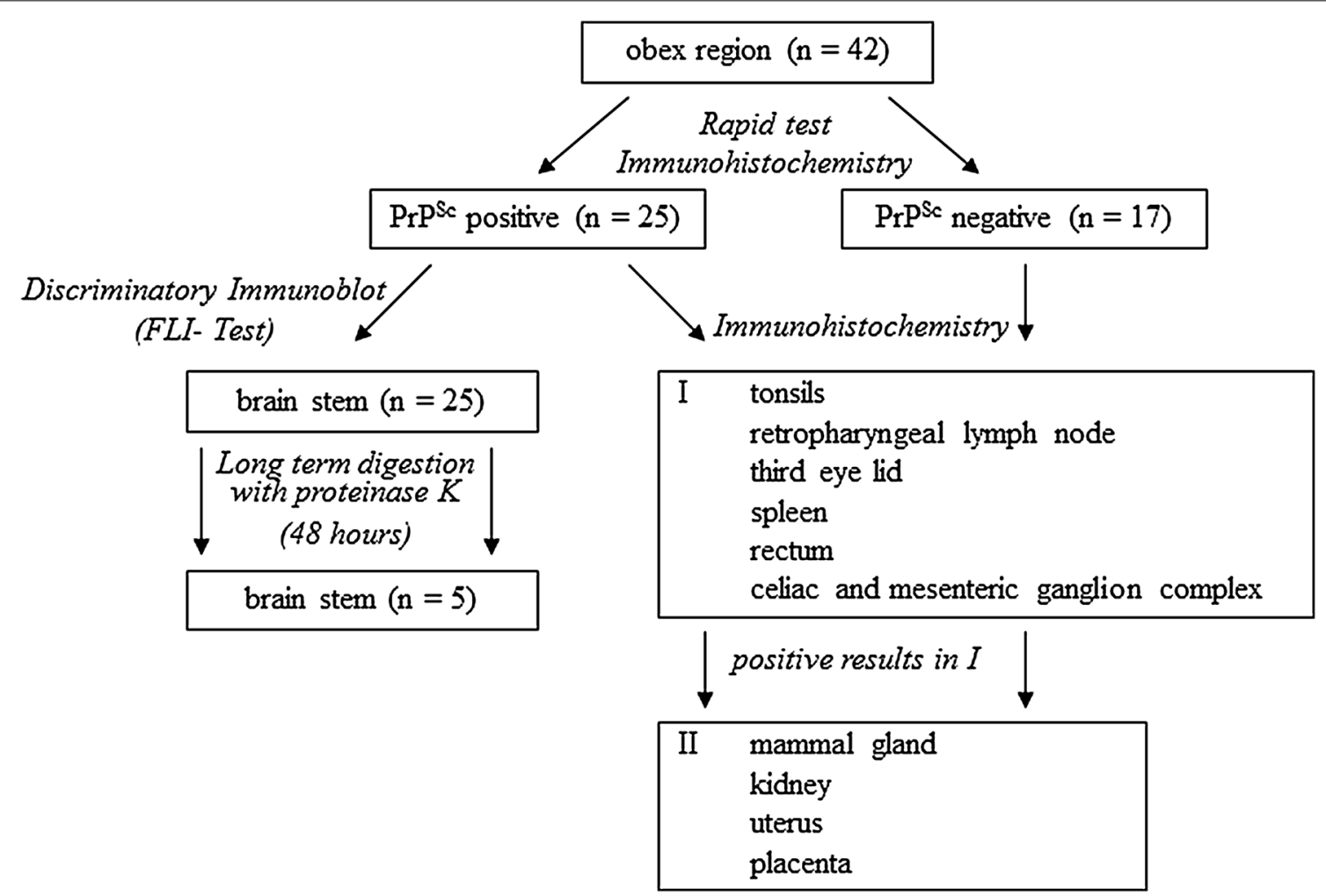

Figure 1 Schema of immunohistochemical and biochemical tests carried out on selected samples of the Cypriot goats. At first, brain stem samples of all 42 goats were examined by different methods. Subsequently the most likely sites of PrPSc accumulations such as the retropharyngeal lymph node, tonsils, third eye lid, spleen, celiac and mesenteric ganglion complex (CMGC) and rectum of all goats were examined by immunohistochemistry (I). In a second step, samples of the kidney, mammary gland, uterus and, if available, placentomal tissue of the placenta were examined with only taking the goats into account which revealed PrPS ${ }^{S c}$ positive results in the tissue samples analysed previously (II). Additionally all positive brain stem samples were examined by discriminatory immunoblot.

at $121^{\circ} \mathrm{C}$ and 3 bar $(6 \mathrm{C} 2$, F99) or pre-treated by proteinase $\mathrm{K}(\mathrm{PK}, 4 \mu \mathrm{g} / \mathrm{mL}$ ) digestion (L42). The primary antibodies were applied at a dilution of 1:50 up to 1:150 (6C2) depending on the stock concentration and 1:10 000 (F99) or 1:250 (L42) in goat serum including $0.03 \%$ sodium azide and incubated for $2 \mathrm{~h}$ at room temperature. The process was finished as described by [47].

\section{Rapid testing and biochemical methods}

Brain stem material of all necropsied goats was primarily analysed in the TSE Section of the Laboratory of Animal Health (LAH) of VS by applying the BioRad TeSeE (München, Germany) rapid test in line with the manual instructions. Optical density (OD) values more than twofold above the cut-off were defined as clear reactive samples.

The identified TSE-positive samples and BSE and scrapie references were additionally analyzed in the discriminatory immunoblot, the so called FLI-test. The latter included a phosphotungic acid (PTA) precipitation of $\mathrm{PrP}^{\mathrm{Sc}}$ followed by SDS-PAGE and immunoblotting, as described before [49] with the following modifications: In general, a $100 \mu \mathrm{L}$-aliquot of brain homogenates was subjected to precipitation. However, depending on the content of $\mathrm{PrP}^{\mathrm{Sc}}$ and the resulting signal intensity obtained from the immunoblot, the volume of brain homogenate varied from $30 \mu \mathrm{L}$ up to $200 \mu \mathrm{L}$. A second precipitation step was included to optimize the original PTA precipitation protocol. First, the resulting pellet was homogenized in $45 \mu \mathrm{L}$ of $50 \mathrm{mM}$ Citrate buffer $(\mathrm{pH} 6.0 / \mathrm{NaOH})$ containing $200 \mathrm{mM} \mathrm{KCl}, 5.0 \mathrm{mM} \mathrm{MgCl}$ and $1.25 \%(\mathrm{w} / \mathrm{v})$ sarcosine. A volume of $0.5 \mu \mathrm{L}$ of thyroglobulin, suspended in bi-distilled water $(5 \mathrm{mg} / \mathrm{mL})$, was added followed by vortexing in $500 \mu \mathrm{L}$ of methanol $(99.8 \%)$ and storage at $-20{ }^{\circ} \mathrm{C}$ for at least $1 \mathrm{~h}$. After centrifugation for $30 \mathrm{~min}$, the supernatant was removed and the pellet was dried under constant shaking at $37^{\circ} \mathrm{C}$. All centrifugation steps were carried out at $17000 \mathrm{~g}$. Finally the pellet was suspended in a sample buffer for SDS-PAGE as described before [51]. The two antibodies mAb L42 and the mAb P4 (R-Biopharm) were selected. As standard marker the FLI-marker was used [50]. Banding patterns were 
revealed using the chemiluminescence substrate CDPStar (Tropix, USA). After incubation for 5 min, emitted light signals were recorded by a photo imager system (Versadoc, Bio-Rad, Germany). Positive controls such as classical ovine scrapie and bovine BSE brain material were included in each assay. Molecular masses were assessed by concurrent FLI-marker [50] and determined by the analysis software Quantity One (BioRad, Germany). The values were calculated as mean \pm SD of at least four independent determinations.

The FLI-test identifies the different cleavage sites of the PK for BSE and scrapie which are varying between the amino acids 96 to 97 and between the amino acids 81 to 89 , respectively. Thus, the persisting $\operatorname{PrP}^{\mathrm{Sc}}$ fragments of BSE are smaller than those of the most scrapie $\mathrm{PrP}^{\mathrm{Sc}}$ fragments after the PK digestion. To discriminate BSE from scrapie three parameters have to be met as described elsewhere [49]. The molecular weight of the un-glycosylated form of the $\mathrm{PrP}^{\mathrm{Sc}}$ has to be compared with the un-glycosylated form of the $\operatorname{PrP}^{\mathrm{Sc}}$ of a positive scrapie control. A BSE isolate shows a lower molecular weight than the scrapie control (of $>0.5 \mathrm{kDa}$ ). In the immunoblot, the $\operatorname{PrP}^{\mathrm{Sc}}$ fragments are visualized using antibody binding sites either at the PrP core region ( $\mathrm{mAb}$ L42) or at an N-terminal site, which is still present in PK treated $\operatorname{PrP}^{\mathrm{Sc}}(\mathrm{mAb} \mathrm{P} 4)$ of scrapie, but removed in that of BSE. Therefore the $\mathrm{mAb} \mathrm{P} 4$ binds to the $\mathrm{PrP}^{\mathrm{Sc}}$ of BSE only weakly or does not bind at all, which results in a $\mathrm{P} 4 / \mathrm{L} 42$ binding ratio of $<0.4$. The epitope specificities of these antibodies have been shown earlier [51]. Finally, following the glycosylation pattern of the $\operatorname{PrP} \mathrm{P}^{\mathrm{Sc}}$, samples are BSE-like when showing a percentage of the diglycosylated form of the total $\mathrm{PrP}^{\mathrm{Sc}}$ signal of $>50.0 \%$.

\section{Analysis of long-term proteinase $\mathrm{K}(\mathrm{PK})$ resistance}

Long term resistance against proteolysis with proteinase $\mathrm{K}$ was determined for five selected isolates after $48 \mathrm{~h}$ exposure. A $600 \mu \mathrm{L}$-aliquot of equally homogenized brain material, diluted with phosphate buffered saline (PBS) to a final concentration of $20 \mathrm{mM}$, was adjusted with magnesium chloride to a final concentration of $1 \mathrm{mM}$ and with benzonase to a final concentration of $50 \mathrm{U} / \mathrm{mL}$ and incubated with PK (final concentration $100 \mu \mathrm{g} / \mathrm{mL}$ ) at $55^{\circ} \mathrm{C}$ and under continuous shaking. After 1, 6, 24 and $48 \mathrm{~h}$ of proteolysis, $150 \mu \mathrm{L}$ each was taken for PTA precipitation of $\operatorname{PrP}^{\mathrm{Sc}}$, which was done without heat denaturizing at $95{ }^{\circ} \mathrm{C}$ for $5 \mathrm{~min}$, followed by SDS-PAGE and immunoblotting and photo imaging as for the FLI-test [49]. The test to determine long term PK resistance was repeated four times for each sample and data were given as the mean of the four independent determinations.

\section{Controls, references and comparative samples}

Control and positive reference material for immunohistochemical and biochemical examinations was taken from ovine, caprine or bovine brain stem samples which had been tested scrapie and BSE-negative or scrapie and BSE-positive, respectively, from the national reference laboratory for transmissible spongiform encephalopathy of the Friedrich-Loeffler Institute (FLI), Isle of Riems, Germany. As comparative samples for biochemical examinations were additionally used BSE-positive brain stem materials, experimental generated in sheep (486; Frederic Lantier, INRA, France) and goat (ZG01; FLI, Germany) and one single scrapie-positive (Stdl. 171) as well as one single bovine sample (R 8/09), which had been submitted for diagnostic purposes to the FLI before.

\section{Statistical analysis}

The statistical analysis was done using the exact Fisher test taking into account a maximum error probability of $5 \%(\alpha=5 \%)$. Consequently, differences [between the results (p)] were only labeled statistically significant with a $p$ smaller $0.05(p<0.05)$. Statistical calculation was done using $\mathrm{R}$ version 2.8.1 (2008).

\section{Results}

The 42 goats which were sourced from the different herds due to scrapie-like clinical signs like alopecia, cachexia and ataxia were tested by BioRad TeSeE rapid test immediately after necropsy. Twenty-five of the samples were tested $\operatorname{PrP}^{\mathrm{Sc}}$ reactive with OD values between 1.069 and 2.204 (cut-off $=0.213$ ) and 17 samples showed clearly negative results with OD values between 0.007 and 0.049 (cut off $=0.213$ ). The rapid test results were confirmed by immunohistochemistry using mAb 6C2.

The TSE positive goats exhibited the $\mathrm{I}_{142} \mathrm{~N}_{146} \mathrm{R}$ ${ }_{151} R_{154} R_{211} Q_{222}$ genotype (wild-type) with one exception (goat ZYP40) that showed a polymorphism at codon 154 (R154H). The goats were two $(n=2)$, three $(n=5)$, five $(n=2)$, six years $(n=1)$ and most of them four years old $(n=15)$. The variability of genotypes was higher among the TSE negative goats, exhibiting in four animals single polymorphisms as N146S $(n=1)$, S146S $(n=1), \mathrm{N} 146 \mathrm{D}$ $(n=1)$ and M142 M $(n=1)$, respectively. In addition, one goat revealed a N146D and a $\mathrm{R} 151 \mathrm{H}$ polymorphism at the same time. Again, most of the TSE negative goats were four years old $(n=5)$, and four goats had been 3 years old. The remaining TSE negative goats were two $(n=3)$, five to six $(n=1$ each) or 7 years old $(n=3)$, which points to a greater number of the younger and the older goats. The compilation of all data can be seen in Tables 1 and 2 . 


\section{Biochemical characterization}

Brain stem samples of the 25 as $\mathrm{PrP}^{\mathrm{Sc}}$ positive identified goats were further characterized using the FLI test. Therein, the glycosylation pattern, the percentage of the di-glycosylated form of the $\mathrm{PrP}^{\mathrm{Sc}}$ and the molecular weight of the non-glycosylated form of the $\mathrm{PrP}^{\mathrm{Sc}}$ were determined for each. In addition, from five selected samples (from the goats ZYP13, ZYP19, ZYP21, ZYP27 and $\mathrm{ZYP} 30)$ the long term resistance against $\mathrm{PK}$ proteolysis was determined over $48 \mathrm{~h}$. For comparative purposes, a caprine (ZG01), an ovine (486) and a bovine BSE sample ( $\mathrm{R}$ 8/09) and an ovine classical scrapie isolate (Stdl. 171) were characterized in the same manner. The molecular weight of the non-glycosylated form of $\mathrm{PrP}^{\mathrm{Sc}}$ was determined to be between 18.0 and $19.4 \mathrm{kDa}$ for the Cypriot caprine scrapie isolates. The ovine scrapie isolate and the caprine, ovine and bovine BSE isolates exhibited molecular weights of $19.2 \mathrm{kDa}, 18.8 \mathrm{kDa}, 18.7 \mathrm{kDa}$ and $18.5 \mathrm{kDa}$, respectively. Referred to the mean of the four to five independent determinations of the molecular weight, only a part of the caprine scrapie isolates $(n=12)$ could be differentiated from the caprine, ovine and bovine BSE isolates. However, all of the Cypriot samples showed a molecular weight of the non-glycosylated form of the $\mathrm{PrP}^{\mathrm{Sc}}$ clearly above the internal BSE reference of each blot. The difference of the molecular weight of the nonglycosylated form of the $\mathrm{PrP}^{\mathrm{Sc}}$ between the Cypriot isolates and the scrapie reference did not exceed $0.5 \mathrm{kDa}$ $(-0.1$ to $0.49 \mathrm{kDa})$. The ovine scrapie isolate (Stdl. 171) showed a comparable result $(0.29 \mathrm{kDa})$, whereas molecular weights of the three BSE isolates were more than
$0.5 \mathrm{kDa}$ smaller than those of the internal scrapie reference $(-0.67$ to $-0.56 \mathrm{kDa}$ ) (Figure 2).

The P4/L42 antibody binding ratio of the Cypriot isolates ranged between 0.69 and 1.76 and thus indicated a clear scrapie-like parameter. In a comparable manner, the ovine scrapie isolate (Stdl. 171) showed an antibody binding ratio of 1.43 . For the caprine, ovine and bovine BSE isolates, however, distinct different ratio values of 0.16 , 0.16 and 0.03 were determined (Figure 2).

The ratio of the di-glycosylated to the mono-glycosylated form of the $\operatorname{PrP}^{\mathrm{Sc}}$ ranged between 43 and 52\%:26 and $32 \%$ for the goat samples, meanwhile for the ovine scrapie sample the ratio was $46: 30 \%$. In contrast, the BSE isolates showed a more dominant di-glycosylated form of the $\mathrm{PrP}^{\mathrm{Sc}}$ with ratios of 62:25\% for the caprine, $59: 26 \%$ for the ovine and $61: 25 \%$ for the bovine BSE sample, respectively (Figure 3). Interestingly, eight of the caprine scrapie isolates showed a percentage of the di-glycosylated form of the $\mathrm{PrP}^{\mathrm{Sc}}$ of $>50 \%$ (ID ZYP13, ZYP17, ZYP19, ZYP25, ZYP27, ZYP29, ZYP30 and ZYP33).

In sum, applying the FLI-test, the Cypriot caprine isolates as well as the ovine scrapie isolate (Stdl. 171) clearly showed scrapie-like biochemical characteristics and BSE could be excluded for the former isolates without any exception. Though eight samples showed a portion of the di-glycosylated form of the $\mathrm{PrP}^{\mathrm{Sc}}$ higher than $50 \%$, which points to BSE-like characteristics, the other two parameters (difference of molecular weight of the non-glycosylated form of the $\mathrm{PrP}^{\mathrm{Sc}}$ to the internal scrapie reference and P4/L42 antibody binding ratio) clearly ascertain scrapie for these isolates.

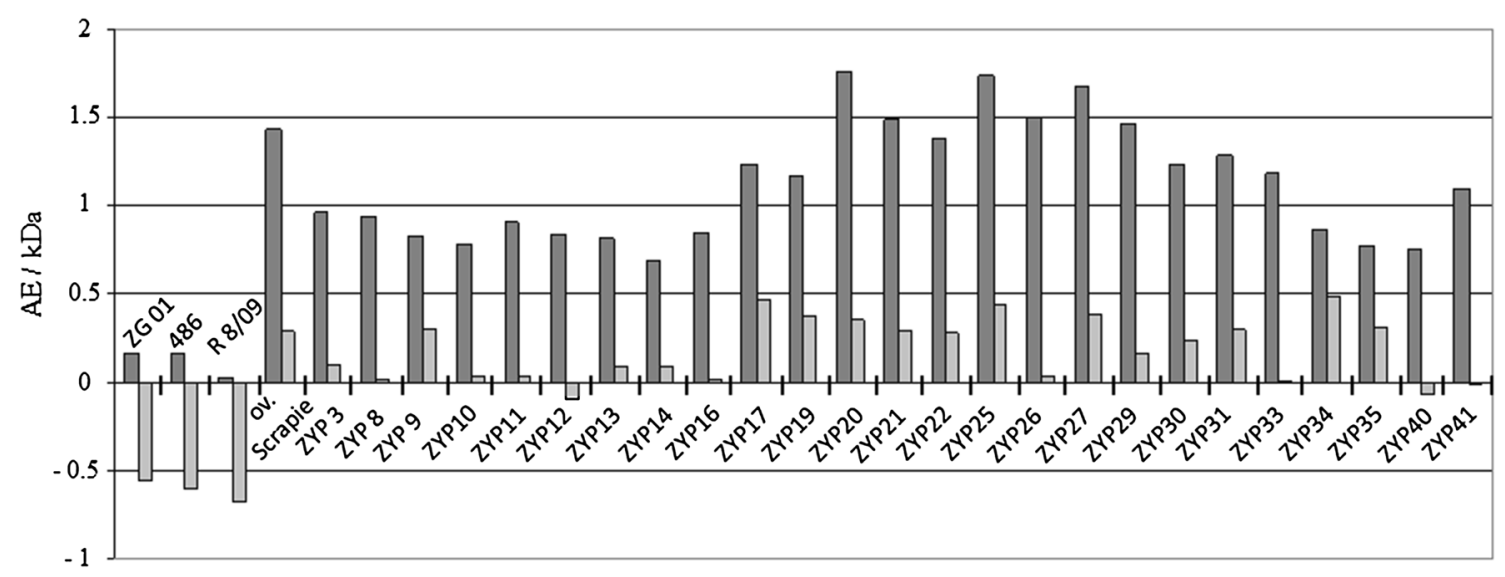

Figure 2 Discriminatory immunoblot of goats with PrP ${ }^{S c}$ accumulation in the brain stem. Antibody-binding ratios P4/L42 and the differences of the molecular weights of proteinase $\mathrm{K}$ treated, unglycosylated $\mathrm{PrP}{ }^{\mathrm{Sc}}$ bands/form in contrast to the molecular weight of the sheep scrapie control are shown of bovine (R8/09), ovine (486) and caprine (ZG01) BSE, of ovine scrapie (Stdl. 171) and all Cypriot caprine scrapie samples. P4/ $L 42$ ratios were calculated as the intensity of the signal strength from P4 versus $L 42$ gained from Western blot. Y-axis: dark grey, P4/L42 antibody binding ratio ( $A E=$ arbitrary unit), data obtained by two gel runs; light grey, difference molecular weight of the un-glycosylated form of the PrPS sample and scrapie control $(\mathrm{kDa})$, data obtained by four to five gel runs. 


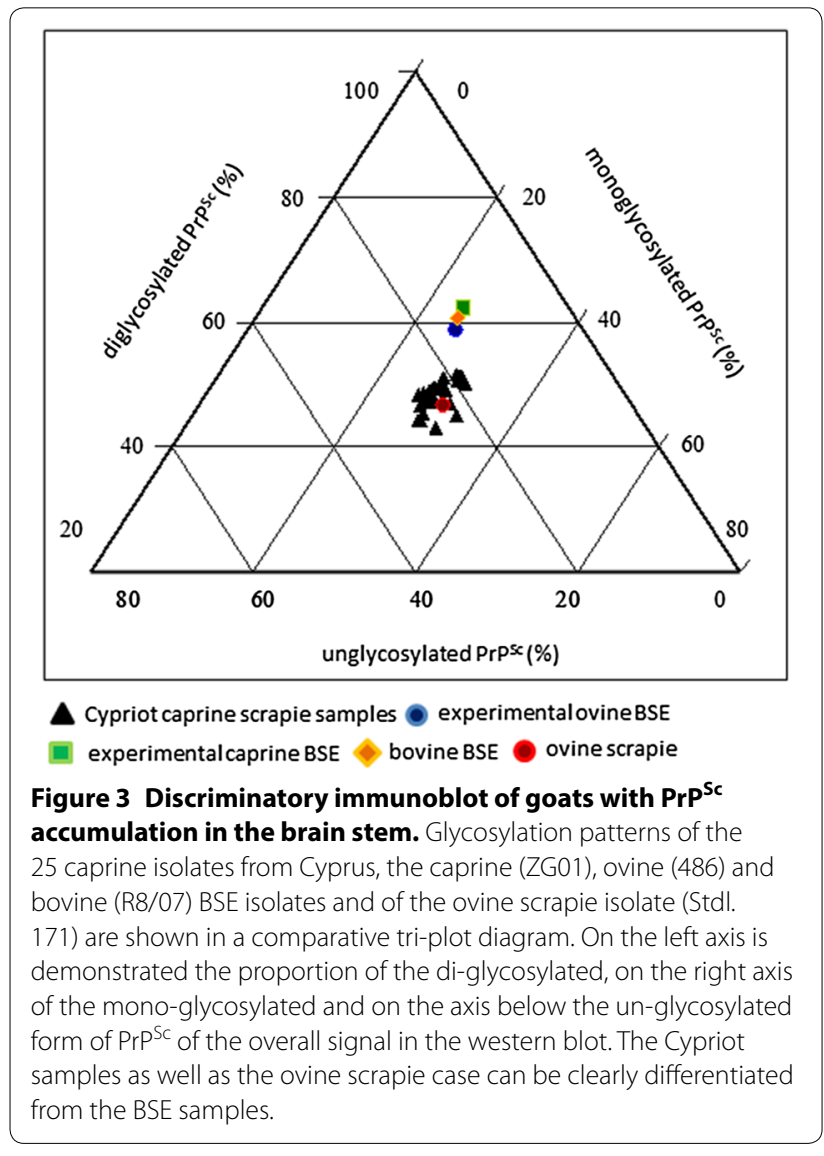

Those goats, showing a percentage of the di-glycosylated form of the $\operatorname{PrP}^{\mathrm{Sc}}$ higher than $50.0 \%$, all of them belonged to the $\mathrm{I}_{142} \mathrm{~N}_{146} \mathrm{R}_{151} \mathrm{R}_{154} \mathrm{R}_{211} \mathrm{Q}_{222}$ wild type genotype coming from neighboring herds. At the same time, goats from the same (herds $\mathrm{G}, \mathrm{H}, \mathrm{K}, \mathrm{M}$ and $\mathrm{O}$ ) and neighboring herds (e.g. herds $\mathrm{F}$ and $\mathrm{P}$ ) were tested scrapie positive showing clearly scrapie-like characteristics for this parameter (Table 1).

Nevertheless, BSE-like characteristics were verified for all control BSE samples of goat, sheep and cattle (ZG 01, 468 and R 8/09), which all fulfil the three criteria of the FLI-test [49].

In addition, the PK resistance was determined for five selected Cypriot goat samples and the ovine and caprine BSE samples. Four of the selected samples revealed in the FLI-test a glycosylation pattern with $>50.0 \%$ of the diglycosylated form of the $\mathrm{PrP}^{\mathrm{Sc}}$ and the one remaining sample (ZYP21) showed typical scrapie-like parameters in the FLI-test as exhibited by most of the Cypriot scrapie isolates. All the five Cypriot scrapie isolates (ZYP13, ZYP19, ZYP21, ZYP27 and ZYP30) tended to a lower proteinase $\mathrm{K}(\mathrm{PK})$ resistance over a $48 \mathrm{~h}$ period than the ovine (486) and caprine (ZG01) BSE reference samples (Figure 4). After 6, 24 and 48 h, 61-72\%, 33-42\% and 20-28\% of the $\mathrm{PrP}^{\mathrm{Sc}}$ of the scrapie isolates remained undigested compared to $75-79 \%, 53-63 \%$ and $33-39 \%$ of the nondigested BSE isolates (Figure 5). Thus the caprine BSE isolate was slightly more resistant against PK digestion.

\section{Histological and immunohistochemical results}

All the 25 goats with a positive reactive Biorad TeSeE rapid test result exhibited in the obex region distinct signs of a spongiform encephalopathy and a clear $\mathrm{PrP}^{\mathrm{Sc}}$ accumulation. For histological and immunohistochemical examinations six regions of the obex region like the dorsal motor nucleus of the vagus nerve (DMNV), the nucleus of the solitary tract, cuneate nucleus, hypoglossal nucleus, spinal tract nucleus of the trigeminal nerve and olivary nuclei were evaluated. Nine of the animals showed mild histopathological alterations which were mainly confined to the DMNV, the nucleus of the solitary tract and most prominent in the spinal tract nucleus of the trigeminal nerve. Nine goats were affected moderately and seven showed severe histological spongiform alterations in most of the brain stem nuclei. Referring to all samples, the olivary nuclei were affected only sporadically.

About half of the samples $(n=13)$ revealed moderate deposits of $\mathrm{PrP}^{\mathrm{Sc}}$ with prominent immunoreactivity in the DMNV, whereas the other half $(n=12)$ was severely affected by $\operatorname{PrP}^{S c}$ depositions. The hypoglossal nucleus, however, was less involved in this process. Using C-terminal antibodies, intra-neuronal, intra-glial and cell-membrane associated/extra-cellular fine up to coarse $\operatorname{PrP}^{\mathrm{Sc}}$ accumulations were detected.

All 25 scrapie-positive animals showed depositions of $\mathrm{PrP}^{\mathrm{Sc}}$ at least in one sample of the LRS and/or the celiac and mesenteric ganglion complex (CMGC), mostly in a moderate up to a severe degree (Figure 6). Two additional goats (ZYP37 and ZYP24)-with no detectable $\mathrm{PrP}^{\mathrm{Sc}}$ in the brain stem-showed positive staining reactions in peripheral samples, only. In both goats mild $\mathrm{PrP}^{\mathrm{Sc}}$ accumulations were detected in the CMGC. ZYP24 showed additional $\mathrm{PrP}^{\mathrm{Sc}}$ deposits in different samples of the LRS. Overall, $\operatorname{PrP}^{\mathrm{Sc}}$ accumulations were of a clear lesser degree as those which were found in the samples of the CMGC and LRS of the goats with $\mathrm{PrP}^{\mathrm{Sc}}$ positive brain stem samples. Not for all goats a complete set of samples was available. Moreover in some LRS and CMGC samples follicles or neurons for the evaluation were missing. An overview concerning the immunohistochemical findings in the peripheral tissues is given in Tables 1 and 2 .

The retropharyngeal lymph node revealed the most frequent $\mathrm{PrP}^{\mathrm{Sc}}$ detection in the LRS (24/24), followed by spleen (24/25), tonsils (18/20), lymphoid follicles of the rectum $(22 / 25)$ and the nictitating membrane $(18 / 26)$. Intracellular fine to coarse $\mathrm{PrP}^{\mathrm{Sc}}$ deposits were detected 

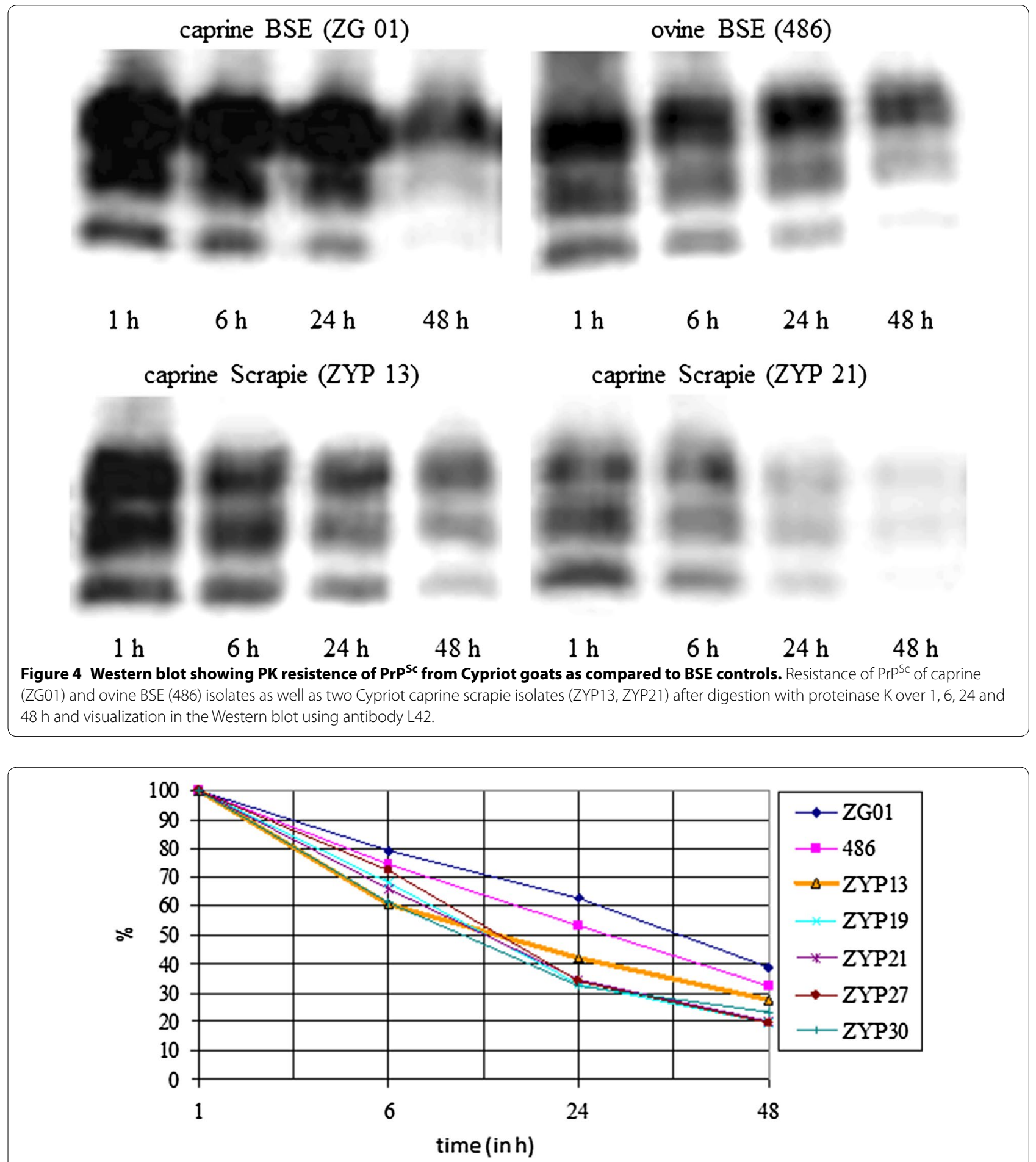

Figure 5 Diagram showing PK resistance of PrPsc from Cypriot goats as compared to BSE controls. Proteinase K-resistance of PrP ${ }^{S C}$ after 1, 6, 24 and 48 h digestion, showing the higher susceptibility of the different scrapie cases (ZYP13, ZYP19, ZYP21, ZYP27, ZYP30) compared to ovine (486) and caprine BSE (ZG01). The signal of the PrPSC in the western blot is shown as a percentage of the overall signal after $1 \mathrm{~h}(=100 \%)$. The data are obtained by four gel runs (ZYP21 = three gel runs).

in tingible body macrophages and lymphocytes as well as in follicular dendritic cells of the LRS. The CMGC showed also frequent mild up to severe $\operatorname{PrP}^{\mathrm{Sc}}$ detection
$(22 / 22)$ with a peri- and intraneuronal staining reaction as well as an intracellular accumulation in associated satellite cells. Multifocally distributed glial cells showed a 


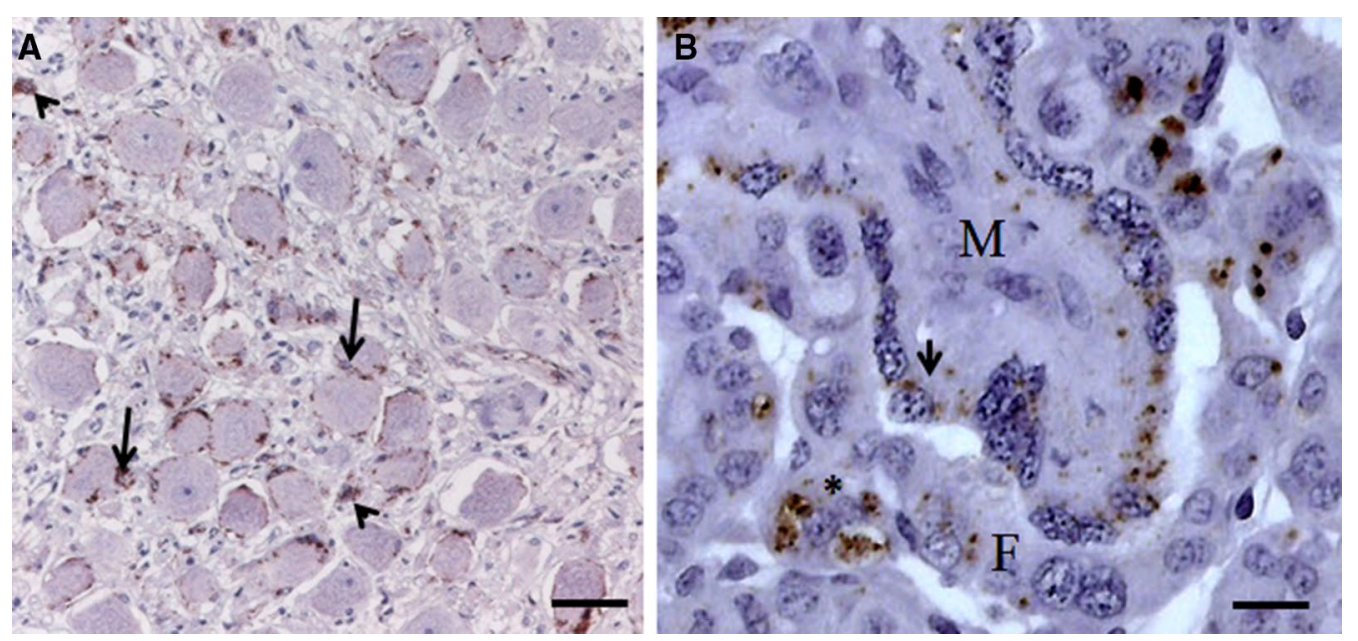

Figure 6 Immunohistochemical detection of $\mathrm{PrP}^{\mathrm{Sc}}$ in autonomic nervous system and placenta. A Celiac and mesenteric ganglion complex of a scrapie infected goat (ZYP30) with moderate accumulation of $\mathrm{PrP}^{\mathrm{Sc}}$. Besides a perineuronal staining reaction, intracellular PrPSc deposits can be seen in associated satellite cells (arrows) as well as in multifocal glial cells (arrowheads); mAb 6C2; bar $20 \mu \mathrm{m} ; \mathbf{B}$ Mild PrPSC accumulations in trophoblasts $\left(^{*}\right.$ ) and epithelial cells (arrow) in placental cotyledons of goat ZYP27. M: maternal parts; F: fetal parts; mAb 6C2, bar $10 \mu \mathrm{m}$.

$\operatorname{PrP}^{\mathrm{Sc}}$ deposition, too (Figure 5A). Intraaxonal $\operatorname{PrP}^{\mathrm{Sc}}$ depositions were seen rarely.

Furthermore, $\operatorname{PrP}^{\mathrm{Sc}}$ accumulations were also detected in the ENS of the rectum (22/26), mostly associated with additional depositions in lymphoid follicles. Neurons and glial cells of both plexus were affected, but more frequently in the myenteric plexus $(21 / 22)$ as compared to the submucosal plexus (12/22). Additionally placental tissue samples from fifteen ewes were analyzed. In doing so, rare intracellular $\mathrm{PrP}^{\mathrm{Sc}}$ depositions were demonstrated in trophoblasts and epithelial cells of the cotyledons from the goats ZYP21, ZYP26 and ZYP27 (Figure 6). No PrP ${ }^{\mathrm{Sc}}$ accumulation was detectable in kidney $(0 / 24)$, mammary gland $(0 / 23)$ or uterus $(0 / 23)$.

\section{Discussion}

In this study 42 goats from 20 different flocks showed clinical signs suspicious for classical scrapie and were culled within the context of a scrapie eradication program in Cyprus. The animals were sourced out by local veterinarians due to unspecific clinical signs which might be indicative for scrapie like alopecia, cachexia and ataxia. However, these signs are not specific for scrapie and there was no possibility for detailed clinical examinations, which explains the comparable high number of negative cases among the animals included in the study. Age distribution of the TSE positive goats was heterogeneous from two up to 6 years of age (mean 3.8 years), which is in accordance with previous reports of classical scrapie in goats $[12,20,52]$. The goats were analysed to get data on genotypic impact on scrapie susceptibility, pathologic pathways of caprine scrapie, and finally to differentiate it from BSE infection applying discriminatory tests.

Twenty-five of these goats were tested scrapie positive and 17 scrapie negative, based on findings in the brain stem samples. In this latter group two goats showed $\mathrm{PrP}^{\mathrm{Sc}}$ deposits in peripheral sites only. Most of the 25 scrapie positive goats belonged to the $\mathrm{I}_{142} \mathrm{~N}_{146} \mathrm{R}_{151} \mathrm{R}_{154} \mathrm{R}_{211} \mathrm{Q}_{222}$ wild type genotype and had widespread $\operatorname{PrP}^{\mathrm{Sc}}$ accumulations in samples of the CMGC, in the LRS and in the rectal ENS. As an exception, one single goat (ZYP40) had peripheral $\mathrm{PrP}^{\mathrm{Sc}}$ depositions, which were restricted to the CMGC (mild accumulations), the retropharyngeal lymph node and to the rectal ENS (severe accumulations). This goat had a R/H polymorphism on codon 154 . Additionally two of the 17 scrapie rapid test negative goats had $\mathrm{PrP}^{\mathrm{Sc}}$ deposits in peripheral sites only, with $\operatorname{PrP}^{\mathrm{Sc}}$ accumulations in the CMGC (ZYP24, ZYP37, both wild type genotypes) and also in the LRS of goat ZYP24.

Nevertheless, in goats with negative $\mathrm{PrP}^{\mathrm{Sc}}$ test results in the brain stem a higher variability of genotypes was demonstrated with one goat combining two polymorphisms relative to the wild type genotype (ZYP39). Therefore reduced susceptibility for scrapie was confirmed for the goats of this study showing at least one PRNP polymorphism (Fisher's exact test $p=0.023$ ) with particularly goats showing polymorphisms at codon 146 being significantly more frequent TSE negative (Fisher's exact test $p=0.016$ ). These observations are in accordance with previous reports, clearly demonstrating a higher resistance of N/D146 and N/S146 PrP gene mutations to natural and experimental scrapie and even a complete resistance of homozygous polymorphisms of this 
type $[12,13,53]$. Additionally, cell-free conversion assays revealed an inhibitory potential of these genotypic variants, too [54]. It cannot be disregarded that the amount of goats examined in this study does not meet the requirements of a representative sample and that only six codons of the PRNP were considered, but still the results support a breeding strategy focussing on codon 146 to control and eradicate classical scrapie from Cyprus [53]. Whether there was any influence on TSE susceptibility due to the polymorphisms R151H and R154H cannot be ruled out in this study, though for the latter protective effects have already been described before $[10,12,16$, 18]. The M/M142 polymorphism was found in a negative goat 3 years of age. This is not surprising as mutations at codon 142 are associated with a lengthened incubation period in experimental inoculations and with increased resistance under natural conditions $[15,17,18]$.

The present study did not reveal any indication that natural BSE occurs in goats of this part of Cyprus. Without exception all TSE positive brain samples of 25 goats including the ovine scrapie isolate (Stdl. 171) were characterized scrapie-like using the discriminatory FLI-test. A BSE case would be only indicated if the glycoform ratio for the diglycosylated form of the $\mathrm{PrP}^{\mathrm{Sc}}$ is higher than $50 \%$, the antibody binding ratio P4/L42 has a lower value than 0.4 and the molecular mass of the unglycosylated band is more than $0.5 \mathrm{kDa}$ lower as compared to the internal scrapie control [49]. Therefore BSE was exclusively determined for the ovine, caprine and bovine BSE control samples. Eight caprine scrapie isolates revealed some discrepancies in the glycosylation pattern showing a diglycosylated form of the $\operatorname{PrP}^{\mathrm{Sc}}$ with more than $50 \%$ of the overall signal which points to BSE-like characteristics. As all other parameters have clear scrapie-like attributes, these isolates were considered as classical scrapie, too. For scrapie in sheep it is well established that differences in biochemical and immunohistochemical properties are indicative for strain diversity in the natural host [49, 55-58]. More recently others reported molecular differences in goat isolates, too [42, 53, 59]. All eight goats are of the same wild type genotype and originate from similar or at least contact herds. Therefore an infection of these goats with the same strain cannot be excluded, but whether the biochemical pattern described here suggests similar strain diversity remain to be clarified by mouse bioassay [60].

In an additional approach four of the eight isolates with discordant biochemical properties and a representative sample from the other scrapie isolates as well as ovine and caprine BSE samples were analyzed by long-term PK digestion over a $48 \mathrm{~h}$ period. In doing so, no clear differences were seen among the caprine scrapie isolates but these were clearly less resistant against PK digestion than the caprine and ovine BSE isolates. The PK resistance of $\operatorname{PrP}^{\mathrm{Sc}}$ was demonstrated to depend on the TSE form [57, 61-63] and recent studies even showed a differentiation of classical scrapie isolates in goats based on the sensitivity to PK digestion at the $\mathrm{N}$-terminal cleavage site [59]. Further studies might show possible species and strain derived influences on the PK resistance.

Most of the scrapie positive tested goats exhibited widespread accumulations of $\operatorname{PrP}^{\mathrm{Sc}}$ in samples of the CMGC and in the ENS as well as in samples of the LRS, most commonly in the retropharyngeal lymph node followed from accumulations in spleen, tonsils, lymphoid rectal tissue and the nictitating membrane. Similar distribution patterns of $\operatorname{PrP}^{\mathrm{Sc}}$ were also reported in classical scrapie affected goats $[42,43,46]$ and sheep [33, 35, 37, 51, 64], respectively. However, one of the scrapie positive goats (ZYP40) revealed besides a moderate accumulation of $\mathrm{PrP}^{\mathrm{Sc}}$ in the obex region only severe $\operatorname{PrP}^{\mathrm{Sc}}$ depositions in the rectal myenteric plexus and mild accumulations in the CMGC. Moreover, a restricted involvement of the LRS was noticed in this goat with mild $\mathrm{PrP}^{\mathrm{Sc}}$ accumulations in the retropharyngeal lymph node, only. The goat was 4 years old and had a R154H polymorphism of the PRNP. In goats the R154H polymorphism was described to be associated with a prolonged incubation period and also with partially protective effects against classical scrapie $[10,12,16]$. Furthermore, a similar pattern was observed in Cyprus [53] and [58] reported influences of the I142M polymorphism on the $\mathrm{PrP}^{\mathrm{Sc}}$ distribution pattern in samples of the caprine central nervous system, LRS and ENS. Thus, concerning goat ZYP40 gene based restriction of $\operatorname{PrP}^{\mathrm{Sc}}$ distribution and the prolonged incubation period might be plausible, though our data were too limited for a proof. Alternatively this pattern could indicate a strain dependent effect. For example in susceptible sheep with a positive reaction in the brain stem a limited involvement of the LRS has also been shown in individual animals [51]. Further studies using mouse bioassays for strain typing purposes might clarify this question.

Moreover, in all scrapie positive goats and one scrapie negative goat (ZYP24) at least one sample was available for ante-mortem diagnosis (tonsil, RAMALT, nictitating membrane) and they always exhibited clear-cut $\operatorname{PrP}^{\mathrm{Sc}}$ deposits. However it has to be emphasized that the comparably high frequency of detectable amounts of $\mathrm{PrP}^{\mathrm{Sc}}$ in the RAMALT in our study is in contrast to the results reported by others, showing only a limited frequency of $\operatorname{PrP}^{\mathrm{Sc}}$ detection in this tissue sample [42]. Additionally, one of the scrapie negative goats (ZG 37) showed a mild $\mathrm{PrP}^{\mathrm{Sc}}$ accumulation in CMGC only and would have been missed by these methods, too. Although a false antemortem diagnostic might happen in individual cases, 
these diagnostic measures could be helpful to differentiate $\mathrm{PrP}^{\mathrm{Sc}}$ positive goats from clinical suspects as shown by others in sheep [64-66].

A less easily accessible sample is the CMGC. It was one of the most frequent $\mathrm{PrP}^{\mathrm{Sc}}$ positive samples, even positive in an otherwise negative goat. To the best of our knowledge such data was never described in scrapie affected goats before. However, [32] described similar findings in scrapie affected sheep indicating a similar early neuronal spread of $\mathrm{PrP}^{\mathrm{Sc}}$ from the ENS via the CMGC to the central nervous system (CNS) in both species. Thus further similarities in caprine and ovine scrapie pathogenesis can be consolidated. However, discrepancies in the $\mathrm{PrP}^{\mathrm{Sc}}$ distribution pattern between our results and others were seen concerning the involvement of the ENS in goat scrapie. In our hands most of the clinical affected animals showed a clear accumulation in neurons and satellite cells of the rectal plexus, a region which is known for ovine classical scrapie to be involved at later stages of the disease [32]. In contrast goats from the UK classical scrapie outbreak [43] showed an only inconsistent accumulation of $\operatorname{PrP}^{\mathrm{Sc}}$ in the ileal ENS, a region which is highly involved in early ovine TSE pathogenesis at least in the highly scrapie susceptible VRQ/VRQ sheep [32]. Additionally in contrast to earlier studies where $\operatorname{PrP}^{\mathrm{Sc}}$ deposits were detected in the kidney of scrapie affected goats [46] and sheep [39] and also in the ovine udder [67], $\operatorname{PrP}^{\mathrm{Pc}}$ was not found in the kidneys and in the udder of the goats of this study. To which extent these patterns are due to the species and genotype of the host, strain diversity and/ or the progress of the disease still needed to be clarified. However, in three out of 15 goats mild $\mathrm{PrP}^{\mathrm{Sc}}$ accumulations were found in the fetal (trophoblasts) and maternal parts (epithelial cells) of the placental cotyledons. This is consistent with other studies in scrapie positive goats [68] and sheep [69]. All three she-goats showed widespread $\operatorname{PrP}^{\mathrm{Sc}}$ deposits in samples of the LRS and in the obex samples implicating that $\operatorname{PrP}^{S c}$ is accumulating in placental tissue at a late stage of scrapie pathogenesis. In sheep, $\mathrm{PrP}^{\mathrm{Sc}}$ accumulation is assumingly highly influenced by the stage of pregnancy and the fetal PRNP genotype $[69,70]$. These two parameters were not captured in this study preventing to draw further conclusions in this item. Nevertheless, it would be of high interest to find out whether placental $\operatorname{PrP}^{\mathrm{Sc}}$ distribution correlates with the state of pathogenesis, to know the influence which is taken by the gestation period and the impact of maternal and fetal PRNP genotype in naturally affected goats together. Moreover, the importance of caprine placenta for scrapie transmission remains to be further clarified.

In summary, a biochemical and immunohistochemical characterization of natural goat TSE cases from different Cyprus herds was performed. The $\operatorname{PrP}^{\mathrm{Sc}}$ was detected in the brain stem of 25 goats and 17 goats provided a negative result. Two of the latter goats exhibited $\mathrm{PrP}^{\mathrm{Sc}}$ deposits in peripheral tissues only. The $\operatorname{PrP}^{\mathrm{Sc}}$ negative goats with assumingly reduced scrapie susceptibility were associated with polymorphisms at codon 146. The discriminatory FLI-test allowed to proof, that all 25 positive brain stem isolates showed clear scrapielike characteristics. However, eight isolates revealed different glycosylation patterns, which might be indicative for the existence of different scrapie strains. To our surprise, goat scrapie isolates showed lower resistance to long term PK digestion than caprine and ovine BSE samples. This fact was very surprising as ovine scrapie was demonstrated to be more resistant to long term PK digestion than BSE from sheep and cattle. However, no differences were seen between the goat isolates. Furthermore, in most goats, $\operatorname{PrP}^{\mathrm{Sc}}$ accumulations were widely distributed within ENS, the LRS and the CMGC. Even samples which are accessible for ante mortem diagnostics (tonsils, RAMALT, third eye lid) were frequently tested $\mathrm{PrP}^{\mathrm{Sc}}$ positive. However, it must be noted, that one goat with a R/H154 polymorphism showed an only minor involvement of the LRS. Further, the present study confirms the presence of $\mathrm{PrP}^{\mathrm{Sc}}$ in trophoblasts and epithelial cells of cotelydons from scrapie-affected goats.

\section{Abbreviations \\ TSE: transmissible spongiform encephalopathy; BSE: bovine spongiform encephalopathy; PrPC/PrPSC: cellular/pathological prion protein; PRNP: prion protein gene; CMGC: celiac and mesenteric ganglion complex; LRS: Iympho- reticular system; ENS: enteric nervous system; RAMALT: rectoanal mucosa- associated lymphoid tissue.}

\section{Competing interests}

The authors declare that they have no competing interests.

\section{Authors' contributions}

SN and CF did the scientific work with the support of ME and TK. The paper was written by SN and CF. The necropsies, sampling and rapid tests were done by SN, CF, MK, II, PPS; CP. PT and TS supervised the work in Cyprus, MHG in Germany. $A B$ and $J L$ were the project leaders of the GoatBSE project. All authors read and approved the final manuscript.

\section{Acknowledgements}

The authors would like to thank Frederic Lantier for the provision of the ovine BSE isolate and Mario Ziller for the statistical analysis. Ulrike Duve, Gesine Kreplin, Daniel Windolph, Magda Hadgiyianni, Anna Theophanous and Maria Charalambous are acknowledged for their excellent technical assistance as well as Eleftheria Chrysanthou, Theodoros Demetriou, Nicos Theophilou and Elena Pieri for their persistent aid performing the necropsies. Many thanks also to Yiola lacovou for the selection of animals.

Ethics approval and consent to participate

The tissue samples were taken within the framework of a scrapie eradication program implemented in Cyprus.

\section{Funding}

This work was financially supported by the EU Commission (Network of Excellence "Neuroprion") and by the GoatBSE project (CT-2006-36353). 


\begin{abstract}
Author details
${ }^{1}$ Institute of Novel and Emerging Infectious Diseases, Friedrich-LoefflerInstitute, Südufer 10, 17493 Greifswald-Isle of Riems, Germany. ${ }^{2}$ Veterinary Services, Ministry of Agriculture, Rural Development and Environment, 1417 Nicosia, Cyprus. ${ }^{3}$ Laboratory of Pharmacology, School of Pharmacy, Aristotle University of Thessaloniki, Thessaloniki, Greece. ${ }^{4}$ Department of Infection Biology, Central Veterinary Institute of Wageningen UR, Lelystad, The Netherlands. ${ }^{5}$ Institute for Hygiene, Westfälische Wilhelms-University and University Hospital Münster, Robert Koch-Strasse 41, 48149 Münster, Germany.
\end{abstract}

Received: 20 May 2016 Accepted: 24 August 2016

Published online: 06 October 2016

\section{References}

1. Prusiner SB (1982) Novel proteinaceous infectious particles cause scrapie. Science 216:136-144

2. Chelle PL (1942) Un cas de tremblante chez la chèvre. Bull Acad Vet Fr 15:294-295 (in French)

3. Parry HB (1962) Scrapie: a transmissible and hereditary disease of sheep. Heredity (Edinb) 17:75-105

4. Wood JL, Lund LJ, Done SH (1992) The natural occurrence of scrapie in moufflon. Vet Rec 130:25-27

5. Wells GA, Scott AC, Johnson CT, Gunning RF, Hancock RD, Jeffrey M, Dawson M, Bradley R (1987) A novel progressive spongiform encephalopathy in cattle. Vet Rec 121:419-420

6. Bruce ME, Will RG, Ironside JW, McConnell I, Drummond D, Suttie A McCardle L, Chree A, Hope J, Birkett C, Cousens S, Fraser H, Bostock CJ (1997) Transmissions to mice indicate that 'new variant' CJD is caused by the BSE agent. Nature 89:498-501

7. Eloit M, Adjou K, Coulpier M, Fontaine JJ, Hamel R, Lilin T, Messiaen S, Andreoletti O, Baron T, Bencsik A, Biacabe AG, Beringue V, Laude H, Le Dur A, Vilotte JL, Comoy E, Deslys JP, Grassi J, Simon S, Lantier F, Sarradin P (2005) BSE agent signatures in a goat. Vet Rec 156:523-524

8. Spiropoulos J, Lockey R, Sallis RE, Terry LA, Thorne L, Holder TM, Beck KE, Simmons M (2011) Isolation of prion with BSE properties from farmed goat. Emerg Infect Dis 17:2253-2261

9. Foster JD, Hope J, Fraser H (1993) Transmission of bovine spongiform encephalopathy to sheep and goats. Vet Rec 133:339-341

10. Vaccari G, Panagiotidis CH, Acin C, Peletto S, Barillet F, Acutis P, Bossers A Langeveld J, van Keulen L, Sklaviadis T, Badiola JJ, Andréoletti O, Groschup $\mathrm{MH}$, Agrimi U, Foster J, Goldmann W (2009) State-of-the-art review of goat TSE in the European Union, with special emphasis on PRNP genetics and epidemiology. Vet Res 40:48

11. Goldmann W, Ryan K, Stewart P, Parnham D, Xicohtencatl R, Fernandez N, Saunders G, Windl O, Gonzalez L, Bossers A, Foster J (2011) Caprine prion gene polymorphisms are associated with decreased incidence of classical scrapie in goat herds in the United Kingdom. Vet Res 42:110

12. Papasavva-Stylianou P, Kleanthous M, Toumazos P, Mavrikiou P, Loucaides P (2007) Novel polymorphisms at codons 146 and 151 in the prion protein gene of Cyprus goats, and their association with natural scrapie. Vet J 173:459-462

13. Papasavva-Stylianou P, Windl O, Saunders G, Mavrikiou P, Toumazos P, Kakoyiannis C (2010) PrP gene polymorphisms in Cyprus goats and their association with resistance or susceptibility to natural scrapie. Vet J 187:245-250

14. Acín C, Martín-Burriel I, Monleón E, Lyahyai J, Pitarch JL, Serrano C, Monzon M, Zaragoza P, Badiola JJ (2013) Prion protein gene variability in Spanish goats. Inference through susceptibility to classical scrapie strains and pathogenic distribution of peripheral PrPSc. PLoS One 8:e6111

15. Goldmann W, Martin T, Foster F, Hughes S, Smith G, Hughes K, Dawson M, Hunter N (1996) Novel polymorphisms in the caprine PrP gene: a codon 142 mutation associated with scrapie incubation period. J Gen Virol 77:2885-2891

16. Billinis C, Panagiotidis CH, Psychas V, Argyroudis S, Nicolaou A, Leontides S, Papadopolous O, Sklaviadis T (2002) Prion protein gene polymorphisms in natural goat scrapie. J Gen Virol 83:713-721
17. Barillet F, Mariat D, Amigues Y, Faugeras R, Caillat H, Moazami-Goudarzi K, Rupp R, Babilliot JM, Lacroux C, Lugan S, Schelcher F, Chartier C, Corbière F, Andréoletti O, Perrin-Chauvineau C (2009) Identification of seven haplotypes of the caprine PrP gene at codons 127, 142, 154, 211, 222 and 240 in French Alpine and Saanen breeds and their association with classical scrapie. J Gen Virol 90:769-776

18. Corbière F, Perrin-Chauvineau C, Lacroux C, Costes $P$, Thomas M, Brémaud I, Martin S, Lugan S, Chartier C, Schelcher F, Barillet F, Andreoletti O (2013) PrP-associated resistance to scrapie in five highly infected goat herds. J Gen Virol 94:241-245

19. Wood JN, Done SH, Pritchard GC, Wooldridge MJ (1992) Natural scrapie in goats: case histories and clinical signs. Vet Rec 131:66-68

20. Capucchio MT, Guarda F, Pozzato N, Coppolino S, Caracappa S, Di Marco V (2001) Clinical signs and diagnosis of scrapie in Italy: a comparative study in sheep and goats. J Vet Med A Physiol Pathol Clin Med 48:23-31

21. Foster JD, Parnham D, Chong A, Goldmann W, Hunter N (2001) Clinical signs, histopathology and genetics of experimental transmission of BSE and natural scrapie to sheep and goats. Vet Rec 148:165-171

22. Hourrigan JL, Klingsporn AL. Scrapie (1996) Studies on vertical and horizontal transmission. In: GIBBS CJ (Ed) Bovine Spongiform Encephalopathy. The BSE Dilemma. Verlag Springer: New York

23. Ryder S, Dexter G, Bellworthy S, Tongue S (2004) Demonstration of lateral transmission of scrapie between sheep kept under natural conditions using lymphoid tissue biopsy. Res Vet Sci 76:211-217

24. Jeffrey M, Gonzalez L (2007) Classical sheep transmissible spongiform encephalopathies: pathogenesis, pathological phenotypes and clinical disease. Neuropathol Appl Neurobiol 33:373-394

25. Van Keulen LJ, Vromans ME, Dolstra CH, Bossers A, van Zijderveld FG (2008) TSE pathogenesis in cattle and sheep. Vet Res 39:24

26. Hoinville LJ (1996) A review of the epidemiology of scrapie in sheep. Rev Sci Tech 15:827-852

27. Terry LA, Howells L, Bishop K, Baker CA, Everest S, Thorne L, Maddison BC, Gough KC (2011) Detection of prions in the faeces of sheep naturally infected with classical scrapie. Vet Res 42:65

28. Konold T, Moore SJ, Bellworthy SJ, Simmons HA (2008) Evidence of scrapie transmission via milk. BMC Vet Res 4:14

29. Lacroux C, Simon S, Benestad SL, Maillet S, Mathey J, Lugan S, Corbière F, Cassard H, Costes P, Bergonier B, Weisbecker JL, Moldal T, Simmons M, Lantier F, Feraudet-Tarisse C, Morel N, Schelcher F, Grassi J, Andréoletti O (2008) Prions in milk from ewes incubating natural scrapie. PLoS Pathog 4:e1000238

30. Maddison BC, Rees HC, Baker CA, Taema M, Bellworthy SJ, Thorne L, Terry LA, Gough KC (2010) Prions are secreted into the oral cavity in sheep with preclinical scrapie. J Infect Dis 201:1672-1676

31. Toumazos P (1991) Scrapie in Cyprus. Br Vet J 147:147-154

32. Van Keulen LJ, Schreuder BE, Vromans ME, Langeveld JP, Smits MA (2000) Pathogenesis of natural scrapie in sheep. Arch Virol 16:57-71

33. Andréoletti $O$, Berthon P, Marc D, Sarradin P, Grosclaude J, van Keulen L, Schelcher F, Elsen JM, Lantier F (2000) Early accumulation of PrP $\mathrm{P}^{\mathrm{SC}}$ in gut-associated lymphoid and nervous tissues of susceptible sheep from a Romanov flock with natural scrapie. J Gen Virol 81:3115-3126

34. Ryder SJ, Dexter GE, Heasman L, Warner R, Moore SJ (2009) Accumulation and dissemination of prion protein in experimental sheep scrapie in the natural host. BMC Vet Res 5:9

35. Van Keulen LJ, Vromans ME, van Zijderveld FG (2002) Early and late pathogenesis of natural scrapie infection in sheep. APMIS 110:23-32

36. Jeffrey M, González L, Espenes A, Press CM, Martin S, Chaplin M, Davis L, Landsverk T, MacAldowie C, Eaton S, McGovern G (2006) Transportation of prion protein across the intestinal mucosa of scrapie-susceptible and scrapie-resistant sheep. J Pathol 209:4-14

37. Jeffrey M, Martin S, Thomson JR, Dingwall WS, Begara-McGorum I, Gonzalez L (2001) Onset and distribution of tissue PrP accumulation in scrapie-affected Suffolk sheep as demonstrated by sequential necropsies and tonsillar biopsies. J Comp Pathol 125:48-57

38. Hunter N, Foster J, Chong A, McCutcheon S, Parnham D, Eaton S, MacKenzie C, Houston F (2002) Transmission of prion diseases by blood transfusion. J Gen Virol 83:2897-2905

39. Sisó S, González L, Jeffrey M (2010) Neuroinvasion in prion diseases: the roles of ascending neural infection and blood dissemination. Interdiscip Perspect Infect Dis 2010:747892 
40. EFSA Panel on Biological Hazards (BIOHAZ) (2009) Scientific Opinion on genetic TSE resistance in goats in all European Union Member States. EFSA J 7:1371-1411

41. EFSA (2010) Scientific Opinion on BSE/TSE infectivity in small ruminant tissues. EFSA J 8:1875

42. González L, Martin S, Sisó S, Konold T, Ortiz-Peláez A, Phelan L, Goldmann W, Stewart P, Saunders G, Windl O, Jeffrey M, Hawkins SA, Dawson M, Hope J (2009) High prevalence of scrapie in a dairy goat herd: tissue distribution of disease-associated PrP and effect of PRNP genotype and age. Vet Res 40:65

43. Gonzalez L, Martin S, Hawkins SAC, Goldmann W, Jeffrey M, Siso S (2010) Pathogenesis of natural goat scrapie: modulation by host PRNP genotype and effect of co-existent conditions. Vet Res 41:48

44. Detwiler LA, Baylis M (2003) The epidemiology of scrapie. Rev Sci Tech 22:121-143

45. Capucchio MT, Guarda F, Isaia MC, Caracappa S, Di Marco V (1998) Natural occurrence of scrapie in goats in Italy. Vet Rec 143:452-453

46. Acutis PL, Martucci F, D'Angelo A, Peletto S, Colussi S, Maurella C, Porcario C, Iulini B, Mazza M, Dell'atti L, Zuccon F, Corona C, Martinelli N, Casalone C, Caramelli M, Lombardi G (2012) Resistance to classical scrapie in experimentally challenged goats carrying mutation K222 of the prion protein gene. Vet Res 43:8

47. Kaatz M, Fast C, Ziegler U, Balkema-Buschmann A, Hammerschmidt B, Keller M, Oelschlegel A, MacIntyre L, Groschup MH (2012) Spread of classic BSE prions from the gut via the peripheral nervous system to the brain. Am J Pathol 181:515-524

48. Harmeyer S, Pfaff E, Groschup MH (1998) Synthetic peptide vaccines yield monoclonal antibodies to cellular and pathological prion proteins of ruminants. J Gen Virol 79:937-945

49. Gretzschel A, Buschmann A, Eiden M, Ziegler U, Lühken G, Erhardt G, Groschup MH (2005) Strain typing of German transmissible spongiform encephalopathies field cases in small ruminants by biochemical methods. J Vet Med B Infect Dis Vet Public Health 52:55-63

50. Groschup MH, Junghans F, Eiden M, Kuczius T (2001) Characterization of Bovine Spongiform Encephalopathy and Scrapie Strains/Isolates by Immunochemical Analysis of PrPsc. In: Baker HF, ed. Molecular Pathology of the Prion. Methods of Molecular Medicine. Totowa: Humana Press Inc

51. Langeveld J, Jacobs J, Erkens J, Bossers A, van Zijderveld F, van Keulen L (2006) Rapid and discriminatory diagnosis of scrapie and BSE in retropharyngeal lymph nodes of sheep. BMC Vet Res 2:19

52. Konold T, Bone G, Simmons MM, Dexter G, Moore SJ, Pettitt RG (2007) Scrapie in goats. Vet Rec 161:395-396

53. EFSA (2012) Scientific and technical assistance on the provisional results of the study on genetic resistance to Classical scrapie in goats in Cyprus. EFSA J 10:2972

54. Eiden M, Soto EO, Mettenleiter TC, Groschup MH (2011) Effects of polymorphisms in ovine and caprine prion protein alleles on cell-free conversion. Vet Res 42:30

55. Benestad SL, Arsac JN, Goldmann W, Noremark M (2008) Atypical/Nor98 scrapie: properties of the agent, genetics, and epidemiology. Vet Res 39:19

56. Stack MJ, Chaplin MJ, Clark J (2002) Differentiation of prion protein glycoforms from naturally occurring sheep scrapie, sheep-passaged scrapie strains (CH1641 and SSBP1), bovine spongiform encephalopathy (BSE) cases and Romney and Cheviot breed sheep experimentally inoculated with BSE using two monoclonal antibodies. Acta Neuropathol 104:279-286
57. Buschmann A, Biacabe AG, Ziegler U, Bencsik A, Madec JY, Erhardt G, Lühken G, Baron T, Groschup MH (2004) Atypical scrapie cases in Germany and France are identified by discrepant reaction patterns in BSE rapid tests. J Virol Methods 117:27

58. Gonzalez L, Siso S, Monleon E, Casalone C, van Keulen LJM, BalkemaBuschmann A, Ortiz-Pelaez A, Iulini B, Langeveld JP, Hoffmann C, Badiola JJ, Jeffrey M, Acin C (2010) Variability in disease phenotypes within a single PRNP genotype suggests the existence of multiple natural sheep scrapie strains within Europe. J Gen Virol 91:2630-2641

59. Pirisinu L, Esposito E, D'Agostino C, Marcon S, Di Bari MA, Lantier F, Acin C, Torres JM, Andreoletti O, Goldmann W, Sklaviadis T, Fast C, Acutis PL, Simon S, Langeveld J, Bossers A, Agrimi U, Nonno R (2013) Biochemical characterization of European goat TSE isolates and discrimination from goat BSE [abstract]. Prion 7(Suppl):27-28

60. Fraser H, Dickinson AG (1968) The sequential development of the brain lesion of scrapie in three strains of mice. J Comp Pathol 78:301-311

61. Kuczius T, Groschup MH (1999) Differences in proteinase K resistance and neuronal deposition of abnormal prion proteins characterize bovine spongiform encephalopathy (BSE) and scrapie strains. Mol Med 5:406-418

62. Sweeney T, Kuczius T, McElroy M, Parada MG, Groschup MH (2000) Molecular analysis of Irish sheep scrapie cases. J Gen Virol 81:2121

63. Klingborn M, Wik L, Simonsson M, Renstrom LH, Ottinger T, Linne T (2006) Characterization of proteinase $\mathrm{K}$-resistant $\mathrm{N}$ - and C-terminally truncated PrP in Nor98 atypical scrapie. J Gen Virol 87:1751-1760

64. Reckzeh C, Hoffmann C, Buschmann A, Buda S, Budras KD, Reckling KF, Bellmann S, Knobloch H, Erhardt G, Fries R, Groschup MH (2007) Rapid testing leads to the underestimation of the scrapie prevalence in an affected sheep and goat flock. Vet Microbiol 123:320-327

65. Ersdal C, Ulvund MJ, Benestad SL, Tranulis MA (2003) Accumulation of pathogenic prion protein ( $\mathrm{PrP}^{\mathrm{SC}}$ ) in nervous and lymphoid tissues of sheep with subclinical scrapie. Vet Pathol 40:164-174

66. González L, Dagleish MP, Bellworthy SJ, Sisó S, Stack MJ, Chaplin MJ, Davis LA, Hawkins SA, Hughes J, Jeffrey M (2006) Postmortem diagnosis of preclinical and clinical scrapie in sheep by the detection of diseaseassociated PrP in their rectal mucosa. Vet Rec 158:325-331

67. Ligios C, Sigurdson CJ, Santucciu C, Carcassola G, Manco G, Basagni M, Maestrale C, Cancedda MG, Madau L, Aguzzi A (2005) PrP ${ }^{\text {Sc }}$ in mammary glands of sheep affected by scrapie and mastitis. Nat Med 11:1137-1138

68. O'Rourke Kl, Zhuang D, Truscott TC, Yan H, Schneider DA (2011) Sparse $\mathrm{PrP}^{\mathrm{SC}}$ accumulation in the placentas of goats with naturally acquired scrapie. BMC Vet Res 7:7

69. Lacroux C, Corbière F, Tabouret G, Lugan S, Costes P, Mathey J, Delmas JM, Weisbecker JL, Foucras G, Cassard H, Elsen JM, Schelcher F, Andréoletti O (2007) Dynamics and genetics of PrPsc placental accumulation in sheep. J Gen Virol 88:1056-1061

70. Andréoletti O, Lacroux C, Chabert A, Monnereau L, Tabouret G, Lantier F, Berthon P, Eychenne F, Lafond-Benestad S, Elsen JM, Schelcher F (2002) $\mathrm{PrP}^{\mathrm{Sc}}$ accumulation in placentas of ewes exposed to natural scrapie: influence of foetal PrP genotype and effect on ewe-to-lamb transmission. J Gen Virol 83:2607-2616

\section{Submit your next manuscript to BioMed Central and we will help you at every step:}

- We accept pre-submission inquiries

- Our selector tool helps you to find the most relevant journal

- We provide round the clock customer support

- Convenient online submission

- Thorough peer review

- Inclusion in PubMed and all major indexing services

- Maximum visibility for your research

Submit your manuscript at www.biomedcentral com/submit 